\title{
EXPLODING THE CLASS ACTION AGENCY COSTS MYTH: THE SOCIAL UTILITY OF ENTREPRENEURIAL LAWYERS
}

\author{
MYRIAM GILLES ${ }^{\dagger}$ \\ GARY B. FRIEDMAN ${ }^{\dagger+}$
}

\section{INTRODUCTION}

John Coffee observed twenty years ago that "[h]igh agency costs" inherent in class action litigation "permit opportunistic behavior by attorneys" and, "[a]s a result, it is more accurate to describe the plaintiff's attorney as an independent entrepreneur than as an agent of the client." Jonathan Macey and Geoffrey Miller picked up on this

\footnotetext{
† Professor, Benjamin N. Cardozo School of Law. Many thanks to participants at workshops and conferences held at UCLA, New York Law School, Washington University, Vanderbilt, Princeton, Northwestern, Cardozo, University of Illinois College of Law, and Florida State University, and especially to Richard Briffault, Arthur Bryant, Edward Cooper, Jill Fisch, Dirk Hartog, Peter Huang, Stan Katz, Liz Magill, Tamir Moustafa, Richard Nagareda, Tom Rowe, Bill Rubenstein, Kim Scheppele, Tony Sebok, Cathy Sharkey, and Stewart Sterk for careful reading and helpful comments. All errors are our own.

${ }^{\dagger}$ Mr. Friedman has represented both defendants and plaintiffs in class actions, and was most recently appointed co-lead counsel in In re American Express Merchants Litigation, No. 03 CV 9592 (GBD), 2006 WL 662341 (S.D.N.Y. Mar. 12, 2006), an antitrust class action on behalf of U.S. retailers.

${ }^{1}$ John C. Coffee, Jr., The Regulation of Entrepreneurial Litigation: Balancing Fairness and Efficiency in the Large Class Action, 54 U. CHI. L. REV. 877, 882-83 (1987) [hereinafter Coffee, Entrepreneurial Litigation]. Professor Coffee has recently posted a paper in which he asserts that "[d] eterrence ... is the only rationale that can justify the significant costs-both public and private-that securities class actions impose on both investors and the judiciary." John C. Coffee, Jr., Reforming the Securities Class Action: An Essay on Deterrence and Its Implementation 2-3 (Columbia Law. Sch. Ctr. for Law \& Econ. Studies, Working Paper No. 293, 2006) [hereinafter Coffee, Securities Class Action], available at http://ssrn.com/abstract_id=893833. Coffee therefore argues that, in order to maximize the deterrent function of these cases, "culpable insiders" should be forced to pay the greater share of financial damages in securities class actions, rather than imposing those costs on the innocent public shareholders of the defendant corporation. $I d$. at 23. This article bears special note here because we think it represents a radical shift in Professor Coffee's approach to the analysis of class actions, and may therefore signal a broader movement in the academy. In other words, if John Coffee-whose influential scholarship in the 1980s spawned a generation of class action skeptics-now views class actions (or, at least, securities class actions) as having social utility in the form of deterrence and has started to engage the question of how to best implement that deterrent power, we are perhaps moving in the right direction. See, e.g., Edward Brunet, Improving Class Action Efficiency by Expanded Use of Parens Patriae Suits and Inter-
} 
theme in a highly influential 1991 article, recognizing that "the single most salient characteristic of class and derivative litigation is the existence of 'entrepreneurial' plaintiffs' attorneys [who, because they] are not subject to monitoring by their putative clients ... operate largely according to their own self-interest ....",

Today, these insights have become canonical. No one doubts that class action plaintiffs' attorneys operate, in reality, as independent entrepreneurs guided by self-interest. ${ }^{3}$ The conventional wisdom further posits that there is tremendous social disutility in the fact that class actions are "characterized by high agency costs: that is, a significant possibility that litigation decisions will be made in accordance with the lawyer's economic interests rather than those of the class."

The conventional wisdom is half right. Class action plaintiffs' lawyers are indeed independent entrepreneurs driven by the desire to maximize their gain, even at the expense of class members' compensation. Where the conventional wisdom has gone wrong, however, is in condemning this as a bad thing and proposing reforms for class action practice designed to correct this conflict by increasing the compensation of absent class members.

In fact, as we will show, the so-called "agency cost" problem is mostly a mirage. So far as the vast majority of small-claims class actions go, ${ }^{5}$ concerns with the undercompensation of absent class mem-

vention, 74 TUL. L. REV. 1919, 1925 (2000) ("Two distinct periods of policy analysis regarding the class action exist. The first era set out the structure for a positive role for the class suit. In great contrast, a second wave of class action thinking, led by Professor Coffee, provided a negative critique of the class action device ...."). Perhaps a third wave has started to form.

2 Jonathan R. Macey \& Geoffrey P. Miller, The Plaintiffs' Attorney's Role in Class Action and Derivative Litigation: Economic Analysis and Recommendations for Reform, 58 U. CHI. L. REV. 1, 7-8 (1991).

${ }^{3}$ See, e.g., Elliot J. Weiss \& John S. Beckerman, Let the Money Do the Monitoring: How Institutional Investors Can Reduce Agency Costs in Securities Class Actions, 104 YALE L.J. 2053, 2088 (1995) ("Most critiques of class actions assume that substantial agency costs are unavoidable because no class member has a stake in the litigation large enough to justify monitoring the attorneys who represent the class.”).

${ }^{4}$ Janet Cooper Alexander, Do the Merits Matter? A Study of Settlements in Securities Class Actions, 43 STAN. L. REV. 497, 536 (1991).

${ }^{5}$ This Article focuses on small-claims class actions, including virtually all consumer class cases, and many claims arising under banking, insurance, and other laws. In recent years, consumer class actions have "accounted for an increasing share of class actions [sic] suits." Edward F. Sherman, Consumer Class Actions: Who Are the Real Winners?, 56 ME. L. REV. 223, 223 (2004). High-value claims falling outside the ambit of 
bers are totally misplaced. In reality, there is generally no legitimate utilitarian reason to care whether class members with small claims get compensated at all. Nor is there any economic reason to fret that entrepreneurial plaintiffs' lawyers are being overcompensated.

There is but one true objective here-one valid normative measure by which to gauge any class action procedure or practice, or any proposed reform. All that matters is whether the practice causes the defendant-wrongdoer to internalize the social costs of its actions. ${ }^{6}$ Once this normative polestar is accepted, much of the recent literature on class actions comes up for reexamination.

The orthodox school of scholarly criticism in the class action area begins its inquiry by focusing on current rules or practices-for example, the rules for awarding attorneys' fees or approving couponbased settlements-and then asking whether current practice optimally aligns incentives to serve the ends of compensating absent class members. $^{7}$ This is the wrong question. Once the appropriate lens of deterrence is applied and the objective of internalization understood, the scholarly view of many of these rules and practices will change dramatically.

The most critical and controversial feature of this argument is that compensation is not really an important goal in small-claims class actions. As discussed in detail below, ${ }^{8}$ we think this conclusion follows from several truths and postulates, including (1) many consumer class actions concern a trifling per-plaintiff sum, which most class members do not care very much about recouping; (2) if the amount at issue is worth chasing, the plaintiff may opt out of the class; (3) the right to be

this Article include many employment, antitrust, and securities actions, and virtually all mass tort class actions.

${ }^{6}$ We recognize that there are externalities associated with class action litigation, so that forcing the defendant to internalize the full costs of its wrongdoing is not costneutral. For a more thorough discussion of these externalities and the balancing of costs and benefits in small-claims class action litigation, see William Rubenstein, Why Enable Litigation?: A Positive Externalities Theory of the Small Claims Class Action, 74 UMKC L. REV. (forthcoming 2006), available at http:/ / ssrn.com/abstract=890303.

${ }^{7}$ See, e.g., John C. Coffee, Jr., Understanding the Plaintiff's Attorney: The Implications of Economic Theory for Private Enforcement of Law Through Class and Derivative Actions, 86 ColuM. L. REv. 669, 726 (1986) [hereinafter Coffee, Understanding the Plaintiff's Attorney] (" $[\mathrm{T}]$ he basic goal of reform should be to reduce the agency costs incident to this attorney-client relationship. While various means to this end are possible . . . all should be understood as responses to this agency cost problem and debated in that light.").

${ }^{8}$ See infra Part II (arguing that class member compensation should not be the primary goal of class suits). 
represented as a passive class member in a Rule 23(b) (3) class action for damages is not one to which parties attach any meaningful value at the time of contracting; and (4) compensating individual small-claims class members is simply not what opt-out class actions do well.

It is not enough to do the hard (or at least counterintuitive) work of showing that class member compensation is irrelevant to the formulation of sound class action policy. We must also do the easy (or at least intuitive) work of showing that the deterrence of corporate wrongdoing is what we can and should expect from class actions. But does anyone seriously doubt that there is immense deterrent power in the contemporary class action? Executives tempted to lie about earnings are more concerned about Bill Lerach and Melvyn Weiss than they are about the Securities and Exchange Commission (SEC). ${ }^{9}$ Companies tempted to skirt fair credit reporting requirements are more concerned with ruinous liability at the hands of the class action bar than they are with the corrective measures and fines that might be meted out following a none-too-likely Federal Trade Commission (FTC) investigation. ${ }^{10}$

A distinct question is whether current rules and practices fail to provide optimal deterrence, either by forcing corporations to internalize costs that go beyond those inflicted upon society, or by allowing

\footnotetext{
${ }^{9}$ See Coffee, Securities Class Action, supra note 1, at 16-17 (suggesting that "securities class actions do seem sufficiently pervasive to constitute a deterrent threat for most public corporations," since "between $2.1 \%$ and $2.8 \%$ of [public companies] have been defendants in securities class actions at the start of each year since 1998”); see also Guy Halfteck, The Law Enforcement Venture: Understanding the Effects of Investment in Class Actions on Corporate Liability Exposure 2 (The John M. Olin Ctr. for Law, Econ., \& Bus. at Harvard Law School, Discussion Paper No. 452, 2004), available at http://ssrn.com/ abstract=497442 ("The fact that billions of liability dollars are internalized by wrongful corporations and other business entities under the aegis of class action litigation and settlement evince the intrinsic capacity of the class action mechanism to enforce the law ....").

${ }^{10}$ The Fair Credit Reporting Act (FCRA), 15 U.S.C. $\$ 1681$ (2000), is a nice case in point: the FTC in recent years has remained on the sideline of litigation brought by the private class action bar against mortgage lenders, banks, and others alleging thousands of violations of FCRA regulations in the distribution of mailers containing "firm offer[s] of credit." Id. $\S 1681 \mathrm{~b}(\mathrm{c})(1)$. The agency has filed amicus briefs on behalf of plaintiffs in these cases, but has otherwise left enforcement of these FCRA provisions solely to the private bar. See Cole v. U.S. Capital, Inc., 389 F.3d 719, 722 (7th Cir. 2004) (noting the FTC's acceptance of the Court's invitation to submit an amicus brief). Further, statutory damages under the FCRA range from $\$ 100$ to $\$ 1000$ per violation, creating enormous incentives for class counsel to bring these claims. See 15 U.S.C. $§ 1681 n(a)(1)$.
} 
them to escape the full costs of their wrongdoing. ${ }^{11}$ These are the right questions, and we should be asking them at every turn as we examine particular rules, practices, and reform proposals in the class action arena. As we will show, this deterrence-centric approach can be expected to yield significantly different results than the standard inquiry in key areas of class action practice, including the rules governing attorneys' fees and the standards to be employed in approving settlements.

In Part I we will canvass the scholarly literature, much of which measures class action practices and reform proposals against implicit or explicit goals of maximizing class member compensation and minimizing "windfall" attorneys' fees. We will show that this state of "compensationalist" hegemony is a relatively recent phenomenon, dating from the 1980s. Before that, some scholars appear at least to have intuited that the true allocative-justice purposes of class actions are served by forcing companies to internalize the costs of their actions, and that the distribution of damages to individual claimants is entirely incidental.

In Part II, then, we will advance the argument that, in assessing the efficacy or desirability of class action practices and reform proposals, any goal of class member compensation must be utterly disregarded in favor of a separate and often competing objective: forcing companies to internalize the social costs of undesirable behavior. We will emphasize that these objectives do in fact compete-that the introduction of compensationalist norms into class action policymaking not only is gratuitous, but also undermines the efficacy of many rules and practices as deterrents. The reflexive inclination to service both objectives, we argue, is unprincipled and often counterproductive.

In Part III we draw extensively on real-world class action practice to demonstrate how the flawed compensationalist model leads to unintended consequences and suboptimal policy choices. We will focus here primarily on the rules governing attorneys' fee awards. So, for example, we will show how attorneys' fee rules that are animated by the misplaced concern of class member compensation have the unintended consequence of misaligning incentives between class and

\footnotetext{
${ }^{11}$ For a discussion of suboptimal deterrence in a related context, see Myriam E. Gilles, In Defense of Making Government Pay: The Deterrent Effect of Constitutional Tort Remedies, 35 GA. L. REV. 845 (2001), which argues that damage awards against government officials and their employers effectively deter constitutional violations.
} 
counsel. In fact, such rules ensure that lawyers will settle cases too cheaply_or at least, far more cheaply than they would under a set of fee rules designed to maximize the defendant's internalization of costs. In the process, we will also demonstrate that, under the current, misguided regime, unethical lawyer activities such as bill-padding and overstaffing actually (and perversely) serve to increase class member compensation. We will also briefly discuss two current hot-button issues in class action practice-coupon-based settlements and class action waivers ${ }^{12}$-in order to show that, here too, a deterrence-based perspective produces results that diverge from the traditional compensationalist view.

In Part IV we will address the critique that current legal rules and our own reform proposals might overdeter undesirable conduct, that is, the concern that the class action device may be (or become) too effective, and may force corporate defendants to internalize costs that exceed the social toll of their undesirable actions. We will also address the underdeterrence concern, focusing on "sell-out" settlement deals and reverse auctions. Concerns about suboptimal deterrence are real and important; indeed, we believe these are the principal concerns that should be addressed in the context of proposals to reform class action rules and practices.

\section{Compensationalist Hegemony}

Once upon a time, scholars considered deterrence of future wrongdoing the strongest justification for small-claims class action litigation. Writing in 1941, Harry Kalven and Maurice Rosenfield warned against restricting the availability of class actions lest we "impair the deterrent effect of the sanctions which underlie much contemporary law."13 Focused as they were on the deterrent, law-

\footnotetext{
${ }^{12}$ See generally Myriam Gilles, Opting Out of Liability: The Forthcoming, Near-Total Demise of the Modern Class Action, 104 MICH. L. REv. 373, 391-412 (2005) [hereinafter Gilles, Opting Out of Liability] (discussing the effects of the increasing prevalence of contractual class action waivers).

${ }^{13}$ Harry Kalven, Jr., \& Maurice Rosenfield, The Contemporary Function of the Class Suit, 8 U. CHI. L. REV. 684, 686 (1941). Kalven and Rosenfield were not entirely dismissive of the class action's potential to achieve "group redress," but they were drawn more to the immense law enforcement potential of these private suits, particularly given the limited resources for enforcement by nascent public agencies in that era. See $i d$. at 715 (noting that private class actions and public administrative enforcement "are not as a practical matter in competition with each other, inasmuch as the administrative law alternative is largely non-existent at the moment"); see also id. at 691 (examin-
} 
enforcement function of class actions, Kalven and Rosenfield were naturally untroubled by the practices that so vex modern commentators:

It is thus seen that the class suit is a vehicle for paying lawyers handsomely to be the champions of semi-public rights.... Because of the lawyer's incentive ... the suit which might not be brought at all because the demands on legal skill and time would be disproportionate to the original client's stake can, when turned into a class suit, be brought and handled in a manner commensurate with its magnitude. Thus, the class suit as a way of redressing group wrongs is a semi-public remedy administered by the lawyer in private practice $\ldots{ }^{14}$

The Kalven-Rosenfield understanding of small-claims class actions and their core public purposes carried over and intensified during the social upheavals of the 1960s. As Judith Resnik has described in great depth:

By the 1960s, lawyers, judges, academics and legislators began to conceive of civil justice as having characteristics readily associated with criminal justice and administrative systems: that it had the potential to serve as a venue for enforcement of public norms .... Creating incentives for entrepreneurial private actors to use the civil justice system to partake in the work of public norm enforcement offered an alternative to centralizing power exclusively within government. [In this moment] of hospitality towards regulation... and of enthusiasm for entrepreneurism, the class action rule was born ... creating a rule regime under which lawyers had incentives to subsidize access to courts for small claimants otherwise unattractive to the contingency fee bar. ${ }^{15}$

In recent years, participants, "practitioners[,] and scholars have told different stories about the forces that motivated the 1966 revision

ing the primary class actions of their day-shareholder derivative suits-and finding a "general agreement that [the class action] furnishes the major sanction behind the fiduciary rules of corporation law"); Judith Resnik, Money Matters: Judicial Market Interventions Creating Subsidies and Awarding Fees and Costs in Individual and Aggregate Litigation, 148 U. PA. L. REV. 2119, 2145 (2000) ("New Deal regulations had focused on the utility of statutory protections for consumers and the desirability of the federal courts as a forum for redress.... Ambivalence about how much government actors could and should do also prompted interest in class action litigation.").

${ }^{14}$ Kalven \& Rosenfield, supra note 13, at 717.

${ }^{15}$ Resnik, supra note 13, at 2144-46; see also Class ACTION Dilemmas: PURSUING PUblic GOALS FOR PRIVATE GAIN 12 (Deborah H. Hensler et al. eds., 2000) (noting that, according to members of the Advisory Committee on the Federal Rules of Civil Procedure, "the committee's deliberations were powerfully affected by the social upheavals of the 1960s"). 
of Rule 23"; ${ }^{16}$ still, it seems fair to say that the Advisory Committee was influenced by the social upheavals of the period and the potential of collective litigation to provide access to justice for small-claims victims of widespread wrongdoing. ${ }^{17}$ As one former committee member recalled to Deborah Hensler, the amendment was infused with "[a] spirit of them versus us, of exploiters who must not exploit the whole population, of a fairly simplistic good guy-bad guy outlook on the world ...." Simultaneously during this period, the concept of the "private attorney general" was gaining momentum, ${ }^{19}$ adding to the perception that litigation could achieve important social goals. ${ }^{20}$

In the late 1960s and 1970s, scholars picked up on the deterrencebased rationale to class actions, seeking ways to study and evaluate this emerging model of private law enforcement. ${ }^{21}$ In the 1972 first edi-

${ }^{16}$ HeNSLER ET AL., supra note 15, at 12.

17 Id.; see also William T. Allen, Commentary on the Limits of Compensation and Deterrence in Legal Remedies, LAw \& CONTEMP. PROBS., Autumn 1997, at 67, 73 ("The widespread adoption of the 1966 federal amendments to the class action rule presents the most obvious and important example of a legal innovation that has the effect of making the compensatory remedy a more effective deterrent.").

${ }^{18}$ HENSLER ET AL., supra note 15, at 12 (quoting John P. Frank, Response to 1996 Circulation of Proposed Rule 23 on Class Actions: Memorandum to My Friends on the Civil Rules Committee (Dec. 20, 1996), in Admin. OfFice of THE U.S. Courts, 2 WORKING PAPERS OF THE ADVISORY COMMITTEE ON CIVIL Rules ON PROPOSED AMENDMENTS TO RULE 23, 266 (1997), http://www.uscourts.gov/rules/ WorkingPapersVol2.pdf). According to Hensler, Frank, a member of the Advisory Committee that revised Rule 23, believed "the committee's deliberations were powerfully affected by the social upheavals of the 1960s," while William T. Coleman, another committee member, rejected "the implication that the 1966 Committee intended to facilitate "private attorneys general' class actions." Id. at 12, 37 n.13; see also Sherman, supra note 5, at 236 ("In the 1970s and 1980s, [the class action] was the workhorse of institutional reform in civil rights and statutory or constitutional remedy litigation.”).

${ }^{19}$ See Resnik, supra note 13, at 2139 (observing that in the 1960s and 1970s some judges began to require "losing defendants to pay victorious plaintiffs' fees and costs based on the view that such private rights enforcement benefited the public and hence that such 'private attorneys general' should be compensated by those whom they sued" (citations omitted)); see also J.I. Case Co. v. Borak, 377 U.S. 426, 432 (1964) (justifying a private cause of action for violation of SEC proxy solicitation rules on the ground that " $[\mathrm{p}]$ rivate enforcement of the proxy rules provides a necessary supplement to" SEC actions, and thus deters future wrongdoing).

${ }^{20}$ See generally William B. Rubenstein, On What A "Private Attorney General" Is-And Why It Matters, 57 VAND. L. REV. 2129, 2133-37 (2004) (sketching the history of the private attorney general concept, and demonstrating that the phrase began to appear with greater frequency in judicial decisions and legal commentary beginning in the late $1960 \mathrm{~s}$ ).

${ }^{21}$ See, e.g., HensLer ET AL., supra note 15, at 39 n.38 (citing Thomas M. Jones, An Empirical Examination of the Incidence of Shareholder Derivative and Class Action Lawsuits, 
tion of his seminal Economic Analysis of the Law, Richard Posner observed of class actions that "the most important point, from an economic perspective, is that the violator be confronted with the costs of his violation-this achieves the allocative purpose of the suit-not that he pays them to his victims." 22 Posner further asserted that "the importance of receipt of damages by the injured party to motivate him to operate the legal machinery is inapplicable here, since the stakes are too small to induce any victim to bear any of the burden of obtaining legal redress." ${ }^{23}$ Posner's views in this regard were largely echoed by other influential scholars in the 1970s, including Kenneth Dam and Arthur Miller. ${ }^{24}$

Things began to change by the early 1980 s, which saw the public emergence of a plaintiffs' class action bar-a group of lawyers willing

1971-1978, 60 B.U. L. REV. 306 (1980) and Barbara Ann Banoff \& Benjamin S. DuVal, Jr., The Class Action as a Mechanism for Enforcing the Federal Securities Laws: An Empirical Study of the Burdens Imposed, 31 WAYNE L. REV. 1 (1984) as examples of empirical studies undertaken in the 1970s evaluating the deterrence rationale); Gerald A. Wright, Note, The Cost-Internalization Case for Class Actions, 21 STAN. L. REv. 383, 411-18 (1969) (analyzing class action cases since the 1966 Rule 23 revisions and concluding that class suits deter companies from wrongdoing by making it possible for those affected by the wrongdoing to hold companies economically liable).

${ }^{22}$ Richard POSNer, ECONOMIC ANALYSIS OF THE LAW 349-50 (1972); see also Halfteck, supra note 9, at $34 \mathrm{n} .101$ (noting that "the ex ante expectations of potential wrongdoers regarding the magnitude of the ex post threat of liability-indeed, the only relevant perspective from a standpoint of deterrence-are solely geared toward the average magnitude of damages; the accurate distribution of damages among individual victims is entirely irrelevant"); William D. Henderson, Clear Sailing Agreements: A Special Form of Collusion in Class Action Settlements, 77 TUL. L. REv. 813, 816 (2003) (citing Posner's economic rationale).

${ }^{23}$ POSNER, supra note 22, at 350.

${ }^{24}$ See Kenneth W. Dam, Class Actions: Efficiency, Compensation, Deterrence, and Conflict of Interest, 4 J. LEGAL STUD. 47, 73 (1975) (concluding that the class action serves the deterrence purpose when "the individual claims are too small to make actual compensation of the class members financially feasible"); Arthur R. Miller, Of Frankenstein Monsters and Shining Knights: Myth, Reality, and the "Class Action Problem", 92 HARV. L. REV. 664, 666 (1979) (asserting that empirical evidence suggests that the 1966 amendments to Rule 23 resulted in some deterrence). But even as early as the 1970 s, a handful of legal scholars were beginning to question the social utility of class action litigation. See, e.g., John P. Dawson, Lawyers and Involuntary Clients: Attomey Fees From Funds, 87 HARV. L. REV. 1597, 1608 (1974) (observing that the common fund concept allows individuals to free ride on attorneys' efforts and "reap where they have not sown"); Francis R. Kirkham, Complex Civil Litigation: Have Good Intentions Gone Awry?, 70 F.R.D. 199 (1976) (asserting that class actions undermine the judicial process); William Simon, Class Actions: Useful Tool or Engine of Destruction, 55 F.R.D. 375 (1973) (suggesting that, on balance, the harms of class action litigation outweigh any social benefit). 
and able to take on complex and risky cases. ${ }^{25}$ This embryonic plaintiffs' class action bar "pooled resources and aggressively shaped litigation across many enterprises and industries, ${ }^{, 26}$ in fields including antitrust, ${ }^{27}$ consumer welfare, ${ }^{28}$ environmental, ${ }^{29}$ and, of course, securities law.

But the dominant public narrative to emerge from these developments did not focus on the resourcefulness and creativity of these legal entrepreneurs, who had managed to realize the deterrent potential of class actions by responding to the private incentives built into the class action device. Instead, the leading stories discussed large fees awarded to class action lawyers ${ }^{31}$ and complaints of "legal blackmail" from settling defendants. ${ }^{32}$

${ }^{25}$ See generally Third Circuit Task Force on Selection of Class Counsel, Third Circuit Task Force Report on the Selection of Class Counsel, 208 F.R.D. 340, 343 n.8 (2002) [hereinafter Class Counsel Report] (citing Jill E. Fisch, Aggregations, Auctions and Other Developments in the Selection of Lead Counsel Under the PSLRA, LAW \& COMTEMP. PROBS., Spring/Summer 2001, at 53, 56) ("[C]lass actions have led to the evolution of entrepreneurial plaintiffs' lawyers, who play a central role in rendering the class action a meaningful vehicle for compensating victims and deterring wrongful conduct."); Coffee, Understanding the Plaintiff's Attorney, supra note 7 (describing the emergence of an efficiency-enhancing plaintiffs' class action bar in securities fraud litigation).

${ }^{26}$ Sherman, supra note 5, at 236; see also Resnik, supra note 13, at 2146 ("By aggregating many small claims together and establishing their legal validity, the victorious lawyer could garnish significant fees through the equitable common fund doctrine. Further, by creating such economic incentives, civil rulemakers helped to develop a cadre of lawyers (some of whom had gained expertise with regulatory regimes by working for the government) with specialized abilities, thereby making somewhat more level the playing field of civil justice when the class action rule was applied.").

${ }^{27}$ See, e.g., In re Corrugated Container Antitrust Litig., 643 F.2d 195 (5th Cir. 1981).

${ }^{28}$ See, e.g., Miner v. Gillette Co., 428 N.E.2d 478 (Ill. 1981).

${ }^{29}$ See, e.g., Ouellette v. Int'l Paper Co., 479 U.S. 481 (1987).

${ }^{30}$ See, e.g., In re Wash. Pub. Power Supply Sys. Sec. Litig., MDL No. 551, 1988 WL 44682 (W.D. Wash. July 14, 1988); In re Pepsico Sec. Litig., 82 CIV. 8403, 1985 WL 44682 (S.D.N.Y. Apr. 26, 1985); In re Baldwin-United Corp. Litig., 607 F. Supp. 1312 (S.D.N.Y. 1985).

${ }^{31}$ See generally HENSLER ET AL., supra note 15, at 15-19 (reviewing popular and business press stories on class actions in the $1970 \mathrm{~s}$, which were universally negative towards these lawsuits and suspicious of the lawyers who brought them); see also In re Fine Paper Antitrust Litig., 98 F.R.D. 48, 68 (E.D. Pa. 1983), rev'd on other grounds, 751 F.2d 562 (3d Cir. 1984) (finding that class counsels' fee applications were "grossly excessive on their face and, regrettably, lend substance to the widely-held and mostly unfavorable impressions of the plaintiffs' class action bar, sometimes referred to as the class action industry”); Ruth Simon, A “Chill” on Class Actions?, NAT'L L.J., Mar. 21, 1983, at 3 (reporting on the Fine Paper Antitrust Litigation, a $\$ 50$ million class action where a judge im- 
Meanwhile, back in legal academia, the dominant story was agency costs. $^{33}$ Beginning with John Coffee's pioneering work in the mid$1980 \mathrm{~s},{ }^{34}$ law and economics scholars began to critically examine the powerful financial incentives of entrepreneurial class action lawyers, concluding that many of the problems that inhered in representative litigation derived from a misalignment of incentives between lawyers and the class. ${ }^{35}$ Because small-claims class members generally "have so little at stake and/or lack such information and expertise that they do not have the incentive or capacity to monitor" their lawyers, contemporary class actions are "characterized by a rent-seeking entrepreneur pursuing her own interests with little oversight by her principals." Plaintiffs' class action lawyers therefore "operate with nearly total

posed "unusually harsh penalties and strong criticism" on the plaintiffs' lawyers for purposely overstaffing the case and submitting a grossly excessive fee request).

${ }^{32}$ See, e.g., HENSLER ET AL., supra note 15, at 33 (discussing the reaction of businesspeople to the burgeoning class action industry).

${ }^{33}$ See, e.g., Brunet, supra note 1, at 1925 ("Two distinct periods of policy analysis regarding the class action exist. The first era set out the structure for a positive role for the class suit. In great contrast, a second wave of class action thinking, led by Professor Coffee, provided a negative critique of the class action device that appears to have worked its way into the court system."); see also Rubenstein, supra note 20, at 2163 (observing that, beginning in the 1980s, "Professor Coffee specifically, and law and economics scholars more generally, proposed rules that sought to reduce agency costs by better align[ing] the interests of the plaintiff's attorney with those of the class members she represented") (quotation marks omitted).

${ }^{34}$ See, e.g., Coffee, Entrepreneurial Litigation, supra note 1; John C. Coffee, Jr., Rescuing the Private Attorney General: Why the Model of the Lawyer as Bounty Hunter Is Not Working, 42 MD. L. REV. 215, 220-21 (1983) [hereinafter Coffee, Rescuing the Private Attorney General] (arguing that the incentives offered to the private attorney general are inadequate and counterproductive in terms of the social interests purportedly served by private enforcement); John C. Coffee, Jr., Rethinking the Class Action: A Policy Primer on Reform, 62 IND. L.J. 625, 626 (1987) (evaluating the incentive structure of large class actions); Coffee, Understanding the Plaintiff's Attorney, supra note 7.

${ }_{35}$ See, e.g., Coffee, Entrepreneurial Litigation, supra note 1, at 879 (noting, for example, that the economic self-interest of plaintiffs' attorneys can lead to a settlement in which all plaintiffs' claims are treated the same); Macey \& Miller, supra note 2, at 19 (observing that normal "bonding and incentive techniques are much less effective" in class action litigation than in traditional litigation); Deborah Rhode, Class Conflicts in Class Actions, 34 STAN. L. REv. 1183, 1191-93 (1982) (arguing that Rule 23's vague requirement that counsel "adequately protect" the interests of class members has led to problems in effective representation); see also Rubenstein, supra note 20, at 2136-38, 2163 (describing how, in the 1980s, law and economics scholars such as John Coffee introduced the concept of agency costs and private entrepreneurial incentives into the debates over class actions).

${ }^{36}$ Rubenstein, supra note 20, at 2162-63. 
freedom," making decisions "largely according to their own selfinterest" ${ }^{38}$ rather than the interests of class members. ${ }^{39}$

"Implicit in the assertion that class actions are characterized by high agency costs is the assumption that such lawsuits primarily serve as a means for claimants to achieve individual ends," ${ }^{40}$ particularly compensatory ends. The agency costs argument quite literally is an argument that lawyers' incentives are not set to maximize class compensation. In this environment of unmanageable agency costs coupled with the lure of high fees, the law and economics scholars argued, one should reasonably expect entrepreneurial lawyers to engage in behavior abusive to the class and detrimental to the goal of compensation. $^{41}$

In the 1990s, "as damage class actions grew in number and scope, both scholarly and public policy discourse on this subject" grew even more focused on the "negative outcomes" of reduced class compensation and high attorneys' fees. ${ }^{42}$ John Frank captured a widely held concern when he complained that

[t]he disproportion of the returns to members of the class and the returns to the lawyers who represent them is often grotesque. In many cases, the individual members of the class are entitled to receive at most a dollar or two, while the attorney who secured this benefaction for them can retire on his share of the victory.

${ }^{37}$ Macey \& Miller, supra note 2, at 20.

Id. at 8.

${ }^{39}$ See, e.g., Steve Coll \& David A. Vise, Shareholder Lawsuits: Profitable Path for Attorneys, WASH. POST, July 24, 1988, at H1 (referring to profitable class action suits as "a game of corporate ambulance chasing").

${ }^{40}$ Lisa L. Casey, Reforming Securities Class Actions From the Bench: Judging Fiduciaries and Fiduciary Judging, 2003 BYU L. REV. 1239, 1261 (2003).

${ }^{41}$ See Deborah R. Hensler \& Thomas D. Rowe, Jr., Beyond "It Just Ain't Worth It": Alternative Strategies for Damages Class Action Reform, LAW \& CONTEMP. PROBS., Summer 2001, at 137, 137 (observing that plaintiffs' class action lawyers may enter into collusive settlements "designed in ways that make it unlikely that the defendants will deliver all of the benefits that they have pledged to pay class members," thereby robbing the class of compensatory benefits).

${ }^{42}$ Id. at 138; see also Nancy J. Moore, Who Should Regulate Class Action Lawyers?, 2003 ILL. L. REV. 1477, 1479 \& n.19 (describing "all of the publicity surrounding allegations of class action abuses" in the 1990s and providing detailed citations to popular and legal articles).

${ }^{43}$ HENSLER ET AL., supra note 15, at 83 (quoting John P. Frank, Response to 1996 Circulation of Proposed Rule 23 Class Actions: Memorandum to My Friends on the Civil Rules Committee, in ADMIN. OFFICE OF THE U.S. COURTS, 2 WORKING PAPERS OF 
By 1996, these twin concerns of high fees and low compensation had reached such a pitch that the Federal Civil Rules Advisory Committee proposed an amendment to Rule 23(b) (3) that would require judges to consider on certification "whether the probable relief to individual class members justifies the costs and burdens of class litigation." As Deborah Hensler reports, this proposal generated controversy over what standards judges should employ to make a cost-benefit analysis at such an early stage in the litigation, and the Committee tabled any action. ${ }^{45}$ What is truly staggering, however, is the extent to which class compensation concerns had come to dominate the reform debate. Only relief to individual class members has any value; gone almost entirely is the original Kalven-Rosenfield understanding of the class action and its allocative purpose of forcing the defendant to internalize social costs.

By the beginning of the new century, nearly all scholars, ${ }^{46}$ commentators, and policymakers had become entirely convinced by ar-

THE AdVisory COMmittee ON Civil Rules on Proposed AMENDMENTS to Rule 23, at 277 (1997)).

${ }^{44}$ Hensler \& Rowe, supra note 41, at 141 (citing Proposed Amendments to the Federal Rules of Civil Procedure, 167 F.R.D. 559, 559 (1996)); see also Robert G. Bone, Rule 23 Redux: Empowering the Federal Class Action, 14 REV. LITIG. 79, 101 (1994) (recommending that any revision to Rule 23 consider the issue of whether small-claim class actions should be allowed). Other important developments during this period include the passage of the Private Securities Litigation Reform Act (PSLRA), which was explicitly intended to create greater monitoring of class counsel by large, institutional investors, as well as to regulate attorneys' fees in securities fraud settlements. See infra text accompanying notes $80-85$.

${ }^{45}$ Hensler \& Rowe, supra note 41, at 143. But see D. Bruce Hoffman, To Certify or Not: A Modest Proposal for Evaluating the "Superiority" Requirement of a Class Action in the Presence of Government Enforcement, 18 GEO. J. LEGAL ETHICS 1383, 1388 n.27 (2005) (noting that while the proposed cost-benefit amendment "was not adopted ... some courts have taken into account the likely costs of a class action, including attorneys' fees, compared to the likely benefit to claimants," and citing Pattillo v. Schlesinger, 625 F.2d 262, 265 (9th Cir. 1980), which affirmed the district court's denial of certification because "any claims paid through the class action procedures would be reduced by the costs of suit and attorneys' fees that plaintiffs sought" and because "the principal beneficiaries of the class action would be plaintiffs' attorneys.").

${ }^{46}$ Notably, Professor David Rosenberg's work in mass torts has remained steadfastly focused on achieving deterrence through aggregation of claims. See David Rosenberg, Decoupling Deterrence and Compensation Functions in Mass Tort Class Actions for Future Loss, 88 VA. L. REV. 1871, 1879-80 (2002) (noting the primacy of deterrence as a function of class action litigation); David Rosenberg, Mandatory-Litigation Class Action: The Only Option for Mass Tort Cases, 115 HARV. L. REV. 831, 839 (2002) (arguing that mandatory-litigation class actions best deter accidents and secure maximum individual welfare). 
guments that class action abuse radiates from the inherent misalignment of interests between class counsel and class members, as evidenced by the exorbitant fees awarded the former at the expense of the latter. ${ }^{47}$

\section{A. Compensationalism in Contemporary Legal Academia}

The entire agency costs argument derives from, or finds cover in, a concern with class member compensation. The relevant literature is teeming with reform proposals aimed at specific features of class action practice, guided by the implicit or explicit normative polestar of class member compensation.

So, for example, a number of scholars have championed the auctioning of lead counsel positions in class actions as a means of ensuring that more bread stays on the plaintiffs' table and less goes to their lawyers. ${ }^{48}$ This literature is explicitly compensationalist: auctions for lead counsel seek to drive down the percent of the fund that counsel is willing to accept as a fee, thereby leaving more of the fund to be distributed among class members. As such, auctions deemphasize many

${ }^{47}$ See Casey, supra note 40, at 1241 (demanding that policymakers "inquire about the results actually achieved for the victims of the fraud"); Christopher R. Leslie, $A$ Market-Based Approach to Coupon Settlements in Antitrust and Consumer Class Action Litigation, 49 UCLA L. REV. 991, 1043 (2002) (noting that agency costs encourage class counsel to pursue their own self-interest at the expense of the class because " $[w]$ hen the attorney has such a substantial financial stake in the outcome of the litigation, the class counsel arguably becomes the principal"); Linda A. Willett, Litigation as an Alternative to Regulation: Problems Created by Follow-On Lawsuits with Multiple Outcomes, 18 GEO. J. LEGAL ETHICS 1477, 1491 (2005) (asserting that benefits to class members "are likely to be disproportionately reduced by compensation for class counsel, which often is obtained at the expense of the lawyers' own clients"); Mohsen Manesh, Note, The New Class Action Rule: Procedural Reforms in an Ethical Vacuum, 18 GEO. J. LEGAL ETHICS 923, 935 (2005) (claiming that class counsel will "exploit" class members by "structuring a settlement deal to compensate the class counsel generously while leaving class members with a recovery of little or no value").

${ }^{48}$ See, e.g., Alon Harel \& Alex Stein, Auctioning for Loyalty: Selection and Monitoring of Class Counsel, 22 YALE L. \& POL'Y REV. 69, 71-72 (2004) (proposing a "servantship" paradigm in which class counsel are kept loyal to their clients through a bidding mechanism); Macey \& Miller, supra note 2, at 106-16 (describing benefits and potential problems of auctioning the lead class counsel position); Julie Rubin, Comment, Auctioning Class Actions: Turning the Tables on Plaintiffs' Lawyers' Abuse or Stripping the Plaintiff Wizards of Their Curtain, 52 Bus. LAW. 1441, 1442 (2003) (arguing that "the class action auction is an alternative that calls for serious experiment"); Analisa Valle, Comment, To the Lowest Bidder? The Private Securities Litigation Reform Act and Auctioning the Role of Lead Counsel, 74 U. COLO. L. REV. 359, 361 (2003) (concluding that the auction process is the "best solution" to the problem of lead counsel selection). 
of the values that guide effective prosecution of claims-experience, funds, support of other class counsel ${ }^{49}$-and catapult one value into preeminence: how little money counsel is willing to accept as a fee..$^{50}$

Other scholars have focused on the "clientless" nature of many contemporary class actions, in which named plaintiffs are incidental formalities $^{51}$ and lawyers really initiate and drive the litigation. ${ }^{52}$ Most prominently, Professor Martin Redish terms these lawyer-driven suits "faux class actions" and asserts they are illegal because they are really whistleblower or qui tam suits brought under substantive statutes, such as antitrust, securities, and consumer laws, in which Congress did

${ }^{49}$ See Class Counsel Report, supra note 25, at 363 n.71 (statement of Sherri R. Savett) ("Experience, resources, and other factors such as accessibility, demeanor, reputation, etc. are all elements that an individual client takes into consideration in selecting an attorney. It is exceptionally difficult for a court to take these factors into consideration when conducting an auction."); $i d$. at 373 (statement of Samuel Issacharoff) ("The auction process fails to take into account the possibility that a higher bidder may have factored in more resources to be put into the action, or is simply a higher quality firm, thereby increasing the possibility of a higher net class recovery. The lowest percentage bidder may simply be lawyers with lesser overhead, lesser ambition, or volume discounters." (quotation marks omitted)).

${ }^{50}$ See generally id. One of the primary reasons the Task Force banished auctions from its districts was for fear that the process would not, in the end, maximize the net recovery to the class. As the authors of the report concluded, "the auction system is more likely to reward attorneys who can bid the lowest by expending the least in prosecution of the class action" and is therefore "not in the best interests of class members." Id. at 373 .

${ }^{51}$ See Richard Nagareda, Administering Adequacy in Class Representation, 82 TEX. L. REV. 287, 374 (2003) (observing that "the inherent nature of the class action [is to be] a vehicle to govern the legal rights of passive class members who are not parties in a conventional sense"); see also Macey \& Miller, supra note 2, at 61 (asserting that "named plaintiffs are-or should be-largely irrelevant in large-scale, small-claim cases and should be eliminated").

${ }^{52}$ See Steven B. Hantler \& Robert E. Norton, Coupon Settlements: The Emperor's Clothes of Class Actions, 18 GeO. J. Legal ETHICS 1343, 1345 (2005) ("As a Wall Street Journal editorial writer explained, "[t]he typical case begins with a lawyer scanning the press for some business miscue so small that no single consumer would bother to complain about it. When thousands of consumers are aggregated in a class action, however, the prospect of a big fee begins to loom.' The Des Moines Register further observed that '[s]ome lawyers have transformed class actions into a major industry, trolling the American marketplace in search of the tiniest flaws in products and services for any opportunity to sue."”); see also Manesh, supra note 47, at 924-25 ("Unlike most litigation, where an injured claimant seeks the attorney, in class actions, the attorney seeks the claimants. From the initial investigation of a claim, to class certification, and finally settlement, class actions are attorney-driven. Before there is ever a class of plaintiffs, an entrepreneurial attorney investigates potential claims, collects facts, recruits an injured plaintiff to serve as the class representative, and files the class action."). 
not see fit to provide qui tam provisions. ${ }^{53}$ Redish's proposal to "weed out" clientless class actions is, at bottom, patently compensationalist: only actions that are brought on behalf of plaintiffs seeking substantial compensation would pass Redish's test of legitimacy.

Relatedly, some scholars and observers have argued that Rule 23 should be amended to provide for opt-in class actions, so that the civil justice system can be properly assured of the claimant's stake in the litigation. $^{54}$ In their view, if small-claims plaintiffs had to opt in to class actions, they would serve as better monitors of class counsel and be certain to demand the fullest possible compensatory award. ${ }^{55}$ Here again, the literature is explicitly driven by a concern that "clientless litigation holds within itself the seeds for questionable practices" ${ }^{\text {"56 }}$ by class action lawyers, namely, reduced compensation to class members.

\footnotetext{
${ }^{53}$ Professor Redish asserts that when a court applies Rule 23 procedures to a substantive federal statute, it is effectively grafting a qui tam provision onto a law that contains no such remedy. As such, he argues that Rule 23 should not be applied to lawyerdriven suits, lest it conflict with the remedial scheme of the substantive congressional enactment upon which the suit is based. Martin H. Redish, Class Actions and the Democratic Difficulty: Rethinking the Intersection of Private Litigation and Public Goals, 2003 U. Chi. Legal F. 71, 77-83; see also Catherine Crier, The CASE Against LaWYers 193 (2002) (citing Professor Lester Brickman as saying that class action lawyers "have invented a formula where they get megabucks ... for being a super legislature and creating a policy to their liking without regard to the right of the electorate to make the ultimate decisions about public policy").

${ }^{54}$ See, e.g., John Bronsteen, Class Action Settlements: An Opt-In Proposal, 2005 U. ILL. L. REv. 903, 903 (2005) (proposing a change in the "default rule so that class settlements include only those who ... opt in"); Edward H. Cooper, The (Cloudy) Future of Class Actions, 40 ARIZ. L. REV. 923, 935 (1998) (suggesting various alternatives to current class action practice, including a proposal that 23 (b) (3) "classes . . be limited to members who affirmatively opt in"); see also Hantler \& Norton, supra note 52, at 1343 (asserting that the 1966 amendment "that reversed an opt-in provision to an opt-out provision ... allows people to be dragooned as plaintiffs in a class action lawsuit unless they affirmatively notify the plaintiffs' attorneys they want out [and that,] as a result, countless thousands of plaintiffs can be conscripted into class actions, often unknowingly").

${ }^{55}$ Related proposals would allow class members numerous opportunities to opt out of class actions. But see generally David Rosenberg, Adding a Second Opt-Out to Rule 23(b)(3) Transactions: Cost Without Benefit, 2003 U. CHI. LEGAL F. 19, 23 (arguing that "any opportunity for exit from the class action will undermine not only the antiredistribution principle-increasing litigation costs and risks from strategic behavior as well as reducing the recoverable wealth that class action scale advantages make possible-but also the basic deterrence objective of collective adjudication").

${ }^{56}$ Deborah R. HENSLER ET Al., RAND InST. FOR CiVIL JUSTICE, ClasS ACTION DILEMMAS: EXECUTIVE SUMMARY 10 (1999), http://www.rand.org/pubs/monograph_reports/ MR969.1/MR969.1.pdf.
} 
Other scholars have become sufficiently concerned with the compensatory consequences of entrepreneurial lawyering to recommend installing external monitors or guardians ad litem to supervise class counsel. $^{57}$ On Professor Alon Klement's proposal, for example, the candidate who submits the highest bid (i.e., the most she would be willing to pay for the monitor position) would be selected and her bid "distributed at the court's discretion either to the class or used to finance part of the class's litigation costs." ${ }^{58}$ Once the monitor is chosen, she would "supervise class attorneys, set their fee, and oversee their conduct in litigation and settlement." ${ }^{59}$ For all this hard work, the monitor would receive a small percentage of the class recovery. Even though this proposal, and others like it, places one more hand into the class action pot, it stems from an explicit desire to increase overall class member compensation by reducing attorneys' fees. ${ }^{60}$

One area that draws more scholarly attention than most is attorneys' fees ${ }^{61}$ - specifically, the issue of how they ought to be determined. ${ }^{62}$ Here, until recently, leading scholars found themselves in a

${ }^{57}$ See Alon Klement, Who Should Guard the Guardians?: A New Approach for Monitoring Class Action Lawyers, 21 REv. LiTIG. 25, 28 (2002); see also Eric D. Green, What Will We Do When Adjudication Ends? We'll Settle in Bunches: Bringing Rule 23 into the TwentyFirst Century, 44 UCLA L. REV. 1773, 1796-97 (1997) (advocating the early appointment of guardians ad litem, by a professor who served as the guardian ad litem for the class in Ortiz v. Fibreboard); Susan P. Koniak, Feasting While the Widow Weeps: Georgine v. Amchem Products, Inc., 80 CORNELL L. REv. 1045, 1090-92 (1995) (proposing the use of a guardian ad litem to protect interests of absent class members against potential collusive behavior by class counsel); Paula B. Wilson, Attorney Investment in Class Action Litigation: The Agent Orange Example, 45 CASE W. RES. L. REv. 291, 327 (1994) (suggesting that attorneys could consult with a guardian ad litem for "additional perspective on the factors involved").

${ }^{58}$ Klement, supra note 57, at 29.

${ }^{59} I d$. at 28.

${ }^{60}$ While Professor Klement would pay a third party "the minimum necessary to motivate" her to actively monitor class counsel, he believes that the end result would be more money for the class itself: "the price class members would have to pay by yielding part of their joint fund would be more than outweighed by their gains from adequate supervision of class attorneys' rents and opportunistic behavior." Id. at 29.

${ }^{61}$ In damages class actions, where class members generally have not signed fee agreements with counsel prior to the litigation, it is left to judges to determine at the end of the case what fees the lawyers will receive from the "common fund." As Deborah Hensler notes, " $[\mathrm{t}]$ he underlying principle is that all who share in the fund should share in paying the class attorney, even though they have not entered into any prior agreement to hire and pay this attorney." HENSLER ET AL., supra note 15, at 77.

${ }^{62}$ See, e.g., William Lynk, The Courts and the Plaintiffs'Bar: Awarding the Attorneys' Fee in Class-Action Litigation, 23 J. LEGAL STUD. 185, 186 (1994) (describing the controversy over methods of determining attorneys' fee awards); Charles Silver, Unloading the Lode- 
bit of a pickle: on the one hand, advocating that class counsel be paid a set percentage of the total recovery secured for the class-the "percent-of-fund" approach ${ }^{63}$ - tends to result in formidably high fees; it is a staple of the class action literature that "windfall" attorneys' fees pose a problem that needs fixing. ${ }^{64}$ On the other hand, the traditional "lodestar" method-under which fees are based on counsel's billed hours multiplied by a reasonable hourly rate, with adjustments made by the court based on risk and quality of work ${ }^{65}$ - was roundly condemned by leading scholars. ${ }^{66}$ As Macey and Miller wrote back in 1991:

star: Toward a New Fee Award Procedure, 70 TEx. L. REv. 865, 869 (1992) (proposing to base "fee awards on fee agreements plaintiffs enter into with other lawyers" and to encourage "lawyers to offer plaintiffs terms that reflect the market value of the services they provide"); see also ARTHUR MILlER, ATtORNEYS' FEES IN CLASS ACTIONS: A REPORT TO THE FEDERAL JUDICIAL CENTER 224 (1980) ("Settlements stipulating the size of plaintiffs' attorneys' fees create a potential for conflict between the attorneys' interest in a large fee and the class interest in a large recovery."); Samuel R. Berger, Court Awarded Attorneys' Fees: What is "Reasonable"?, 126 U. PA. L. REV. 281, 283 (1977) (describing the "confused and conflicting state of the law" on the question of how to determine reasonable attorneys' fees).

${ }^{63}$ See Third Circuit Task Force on Court Awarded Attorney Fees, Report of the Third Circuit Task Force on Court Awarded Attorney Fees, 108 F.R.D. 237, 258 (1985) [hereinafter Attorney Fees Report] (describing the percent-of-fund approach to fee-setting).

${ }^{64}$ There are literally scores of articles and reports dealing with the perceived "windfall" problem. See, e.g., Hensler ET AL., supra note 15, at 77 (noting the criticism that the [percent-of-fund] method led to "excessive fees that were unrelated to the actual effort expended by plaintiff class action attorneys"); Macey \& Miller, supra note 2, at 23-24 (noting the "obvious incentive problems" with the percent-of-fund method: "plaintiffs' attorneys will earn windfall profits, at the expense of the class members, in cases presenting large damages and low proof costs," and the method "effectively guarantees that plaintiffs' attorneys will be systematically compensated at a rate higher than the rate they would demand in an efficiently functioning competitive market"); Martha Pacold, Attorneys' Fees in Class Actions Governed by Fee-Shifting Statutes, 68 U. CHI. L. REV. 1007,1021 (2001) (observing that courts have viewed the percent-of-fund approach as "problematic because it generate[s] windfalls for attorneys with exceptionally large funds"); see also Attorney Fees Report, supra note 63, at 242 (noting that "[p]ress reaction to these [high attorneys' fee] awards, and criticism from within the profession that the fees were disproportionate to the actual efforts expended by the attorneys, generated pressure to shift away from the percentage-of-recovery approach").

${ }^{65}$ Klement, supra note 57, at 35 n.27; Attorney Fees Report, supra note 63, at 256.

${ }^{66}$ See, e.g., Coffee, Understanding the Plaintiff's Attorney, supra note 7, at 691 ("By severing the fee award from the settlement's size, [the lodestar] formula facilitates the ability of defendants and the plaintiff's attorneys to arrange collusive settlements that exchange a low recovery for a high fee award."); Howard M. Downs, Federal Class Actions: Diminished Protection for the Class and the Case for Reform, 73 NEB. L. REV. 646, 667 (1994) (noting that under the lodestar method of fee-setting lawyers can "pad their hours and otherwise engage in unethical activities to enhance their fees"). 
The lodestar approach has three principal, related defects: it involves enormously burdensome circulation costs; it encourages attorneys to exaggerate their hours; and, because it guarantees that the attorneys will receive their fees if successful, it fails to give plaintiffs' attorneys the proper incentive to strike a settlement agreement that maximizes recovery for the plaintiff class.

The widely hailed solution to the percent-of-fund versus lodestar problem was the so-called "lodestar cross-check," which really began to take hold in the mid-1990s. ${ }^{68}$ Under this system, the starting point for awarding attorneys' fees is a reasonable percent of the fund created, which the court then "cross-checks" against the lawyers' billing records to protect against windfall fees. As the Third Circuit has explained, courts "cross-check the percentage award counsel asks for against the lodestar method of awarding fees so as to insure that plaintiffs' lawyers are not receiving an excessive fee at their clients' expense." ${ }^{69}$ As this quote emphasizes, the lodestar cross-check-which has now become the dominant approach in most federal circuits ${ }^{70}$-is explicitly rooted in the value of promoting class member compensation and minimizing agency costs.

These are but a smattering of examples. Law library shelves sag with compensationalist/anti-windfall fees/agency cost-based critiques of nearly every aspect of class action practice, including the rules for approving settlements, ${ }^{71}$ particularly coupon-based settlements; ${ }^{72}$ com-

${ }^{67}$ Macey \& Miller, supra note 2, at 4.

68 See Vaughn R. Walker \& Ben Horwich, The Ethical Imperative of a Lodestar CrossCheck: Judicial Misgivings About "Reasonable Percentage" Fees in Common Fund Cases, 18 GEO. J. LEGAL ETHICS 1453, 1454 (2005) (observing that while the percent-of-fund model enjoyed a brief recovery in the 1990s, its "revival has in the last decade prompted a judicial countermarch in the form of a lodestar cross-check or test of the reasonable percentage by reference to reasonable hours and rates") (quotation marks omitted); see also Casey, supra note 40, at 1277, 1302 (describing the prevalence of the percent-of-fund approach during the 1990s and the emergence of the lodestar crosscheck in this century).

${ }^{69}$ Gunter v. Ridgewood Energy Corp., 223 F.3d 190, 199 (3d Cir. 2000).

${ }^{70}$ Walker \& Horwich, supra note 68, at 1460 (noting that, "[b]y 2000, the practice [of using the cross-check] was apparently routine enough for one district court in the Third Circuit to remark that "[t]raditionally, the "appropriate" percentage [fee award] is . . subjected to a cross check"” (quoting In re Cendant Corp. Sec. Litig., 109 F. Supp. 2d 285, 302 (D.N.J. 2000), vacated 264 F.3d 201 (3d Cir. 2001); id. at 1463 (observing that "48 district court decisions after $2000 \ldots$ applied some form of lodestar crosscheck").

${ }^{71}$ See, e.g., Bruce Hay \& David Rosenberg, "Sweetheart" and "Blackmail" Settlements in Class Actions: Reality and Remedy, 75 Notre DAME L. REv. 1377, 1379 (2000) (arguing that the risks of class action suits settling for far more or far less than they should "can 
pensating lead plaintiffs; ${ }^{73}$ and certifying classes,${ }^{74}$ among many other matters.

\section{B. Compensationalism in Congress, the Courts, and Government Agencies}

Policymakers have proven especially receptive to the views of legal academics in the class actions area. The discourse on class action reform has been markedly law-professor-driven, ${ }^{75}$ as prominent scholars have testified to and been widely cited by congressional committees, ${ }^{76}$ judicial task forces, ${ }^{77}$ and advisory committees. ${ }^{78}$

effectively be handled by courts through appropriate class action safeguards"); Geoffrey P. Miller, Some Agency Problems in Settlement, 16 J. LEgAL STUd. 189, 189 (1987) (examining the economics of settlement in cases where more than one person has an interest in the claim).

${ }^{72}$ See, e.g., Christopher R. Leslie, A Market-Based Approach to Coupon Settlements in Antitrust and Consumer Class Action Litigation, 49 UCLA L. REV. 991, 994 (2002) (demonstrating how promotional coupon settlements are worthless to many class members); Geoffrey P. Miller \& Lori R. Singer, Nonpecuniary Class Action Settlements, LaW \& CONTEMP. PROBS., Autumn 1997, at 98, 98 (analyzing the costs and benefits of nonpecuniary class action settlements).

${ }^{73}$ See, e.g., Jill E. Fisch, Class Action Reform, Qui Tam, and the Role of the Plaintiff, LAW \& CONTEMP. PROBS., Autumn 1997, at 167, 169 ("Empowering the class representative enables the client to exercise greater control over class counsel and the conduct of the litigation [and] [t] his should lead to a greater emphasis on recourse and victim compensation."). But see Theodore Eisenberg \& Geoffrey P. Miller, Incentive Awards to Class Action Plaintiffs: An Empirical Study, 53 UCLA L. REV. 1303, 1307-08 (2006) (finding, based on a study of 374 class actions, that incentive awards to representative plaintiffs were granted in only $28 \%$ of settled cases and constituted, when given, on average, merely $0.16 \%$ of class recovery).

${ }^{74}$ See, e.g., Richard A. Epstein, Class Actions: Aggregation, Amplification, and Distortion, 2003 U. CHI. LEGAL F. 475, 478-79 (discussing the inherent imperfections of aggregating small claims and combining parties); Charles Silver, "We're Scared to Death": Class Certification and Blackmail, 78 N.Y.U. L. REV. 1357, 1429 (2003) (rejecting the argument that class action defendants are blackmailed into settlements and arguing instead that " $[\mathrm{t}]$ he problem, assuming it exists, is excessive pressure resulting in decisions to settle made under duress").

${ }^{75}$ See John Leubsdorf, Co-Opting the Class Action, 80 CORNELL L. REV. 1222, 1223 (1995) (describing the class action as "an institution that lawyers and scholars have shaped").

${ }^{76}$ See, e.g., Ten Things We Know and Ten Things We Don't Know About the Private Securities Litigation Reform Act of 1995: Joint Written Testimony Before the Subcomm. on Sec. of the S. Comm. on Banking, Hous., E Urban Affairs, 105th Cong. (1997) (testimony of Joseph A. Grundfest \& Michael A. Perino) available at http://securities.stanford.edu/ research/articles/19970723sen1.html (discussing the effects of the Reform Act on securities class actions).

${ }^{77}$ See, e.g., Class Counsel Report, supra note 25, at 357 n.38, 399 n.217, 400 n.223, 402 n.229, 408 n.255 \& 412 n.271 (2002) (accepting prepared statements by various 
Small wonder, then, that the academic preoccupation with class member compensation has become the starting and ending point in public policy debates over class action reform. Contemporary political debates over class action reform center on two assertions: that these suits are "seriously injuring the consumers that [they] are supposed to benefit" by failing to compensate them adequately for their injuries, and that "counsels walk off with enormous attorneys' fees but the class members receive next to nothing."

Legislative reforms, such as the 1995 Private Securities Litigation Reform Act (PSLRA) ${ }^{80}$ and the 2005 Class Action Fairness Act (CAFA) ${ }^{81}$ have been explicit in their intent to provide more meaningful investor and class member compensation. Congress enacted the PSLRA, over President Clinton's veto, after hearing copious testimony "suggest[ing] that class members recover low percentages of their recognized losses in class actions," and that large institutional investors "might well be able to generate substantial net benefits by acting as litigation monitors." 82 As a result, the PSLRA sought to "overcome the concern that securities class actions are "lawyer-driven"” ${ }^{\prime 3}$ by re-

law professors, including Arthur Miller, Joseph Grundfest, John Coffee, Elliot Weiss, Jill Fisch, and Lucian Bebchuk, in addition to citing extensively from legal scholarship).

${ }^{78}$ Law professors have chaired, testified before, and participated in numerous meetings of the Advisory Committee on Civil Rules. They have also organized in opposition to various proposed amendments. See, e.g., Letter from Steering Committee To Oppose Proposed Rule 23 to Honorable Alicemarie H. Stotler (May 28, 1996), in ADMIN. OFFICE OF THE U.S. COURTS, 2 WORKING PAPERS OF THE ADVISORY COMMITTEE on Civil Rules on Proposed Amendments to Rule 23, at 1 (1997), http://www.uscourts.gov/rules/WorkingPapers-Vol2.pdf.

${ }_{79}$ Class Action Fairness Act of 2001: Hearing on H.R. 2341 Before the H. Comm. on the Judiciary, 107th Cong. 37-38 (2002) [hereinafter Class Action Fairness Act Hearing] (testimony of John Beisner, partner, O’Melveny \& Myers, LLP), available at http://commdocs.house.gov/committees/judiciary/hju7757.000/hju7757_0f.htm.

${ }^{80}$ Pub. L. No. 104-67, 109 Stat. 737 (codified as amended in scattered sections of 15 U.S.C.).

${ }^{81}$ Pub. L. No. 109-2, 119 Stat. 4 (to be codified in scattered sections of 28 U.S.C.).

${ }^{82}$ Weiss \& Beckerman, supra note 3 , at 2089. The authors, writing in the mid1990 s, recognized that there had been significant debate over investor compensation via securities class action litigation. See id. at 2089 n.199 (citing conflicting testimony of Edward J. Radetich that "recoveries average 13.5455\% of investors' losses" and testimony of class action lawyer William S. Lerach that "claimants receive about 60 percent of their recoverable damages") (internal citations omitted).

${ }^{83}$ James D. Cox \& Randall S. Thomas, Letting Billions Slip Through Your Fingers: Empirical Evidence and Legal Implications of the Failure of Financial Institutions To Participate in Securities Class Action Settlements, 58 STAN. L. REV. 411, 417 (2005); see also Richard H. Walker et al., The New Securities Class Action: Federal Obstacles, State Detours, 39 ARIZ. L. 
quiring that the court appoint as lead plaintiff the representative with the "largest financial interest" in the suit ${ }^{84}$ - the assumption being that "an investor with a sufficiently large financial stake in the suit will be a more diligent monitor than a person with a miniscule claim in the suit who may well even have been selected by the suit's attorney."

More recently, supporters of CAFA—for which the U.S. Chamber of Commerce and other business groups strongly lobbied five sessions of Congress before finally succeeding in getting the statute enacted in $2005^{86}$-were explicit in their intent to protect class members' wallets from avaricious plaintiff's lawyers. ${ }^{87}$ House member Bob Goodlatte, who first introduced CAFA in 2001, asserted that the intent of the bill was to help "the class member whose claim is extinguished by the settlement, at the expense of counsel seeking to be the one entitled to recovery of fees." 88 A Republican-sponsored Senate report echoed this view that CAFA would help curb "excessive attorney fee awards [that come] at the expense of injured plaintiffs" and would guarantee greater judicial oversight of class "settlements [that] consist of extravagant payments to plaintiffs' attorneys and nothing of real value to

REV. 641, 642 (1997) (asserting that the "central theme of the legislative history [of the PSLRA] is that plaintiffs' lawyers, rather than faithfully representing investors, were acting for their own benefit").

${ }^{84} 15$ U.S.C.A. § 78u-4(a) (3) (B) (iii) (I) (bb) (West Supp. 2005). As one commentator notes:

In making this appointment, the court is required to take into account the size of the financial stake of any potential class representative [which] increases the possibility that a real client with a significant interest in the dispute will be involved in the litigation, [and this i] n turn, may offset the self-interest of class counsel, who might otherwise be unaccountable.

Louis W. Hensler III, Class Counsel, Self-Interest and Other People's Money, 35 U. MEM. L. REV. 53, 81 (2004).

${ }^{85}$ Cox \& Thomas, supra note 83 , at 417 .

${ }^{86}$ Sherman, supra note 5 , at 230.

${ }^{87}$ See, e.g., 151 CONG. REC. S1178 (daily ed. Feb. 9, 2005) (statement of Sen. Hatch) (observing that "many of today's class actions are nothing more than business opportunities for some lawyers to strike it rich and too often have little, if anything, to do with fairly compensating injured class members"); see also John F. Harris \& Jim VandeHei, Senate Nears Revision of Class Actions, WASH. POST, Feb. 10, 2005, at A4 (reporting on Senator Hatch's speech denouncing the "jackpot justice" of class action litigation and describing a particular case in which "lawyers made $\$ 1.5$ million suing $\mathrm{K}$ B Toys, while the plaintiffs got an offer to buy more merchandise at a 30 percent discount").

${ }^{88}$ Class Action Fairness Act Hearing, supra note 79, at 13 (statement of Rep. Goodlatte). 
the injured plaintiffs." ${ }^{89}$ Corporate defense lawyers showed their concern for plaintiffs, testifying that CAFA was necessary to stop "settlements that provide only nominal benefits to the people who are ostensibly being represented-the class members themselves-while offering a bonanza in attorneys' fees for the plaintiffs' lawyers." ${ }^{90}$ Media outlets focused their considerable coverage of CAFA on this theme as well. ${ }^{91}$ As other reform bills continue to be presented and debated in Congress, it seems clear that legislators will remain susceptible to compensationalist arguments. ${ }^{92}$

The FTC has also focused a great deal of recent attention on class compensation and reducing attorneys' fees, as evidenced by a series of new agency directives. For example, the FTC has started to challenge class action settlements by "filing amicus briefs opposing class settlements [where] class relief seems too low or the attorneys' fees egre-

${ }^{89}$ U.S. Senate Republican Policy Comm., Legislative Notice, S.5-The Class Action Fairness Act (Feb. 4, 2005), http://rpc.senate.gov/_files/L1ClassActionSD020405.pdf.

${ }^{90}$ Class Action Fairness Act Hearing, supra note 79, at 50 (testimony of John Beisner).

91 See, e.g., Editorial, The Class Action Money Chase, CHI. TRIB., June 18, 2003, at 18 ("Federal courts are ... more likely to dismiss class-action suits. So it's no wonder that trial lawyers are up in arms about this legislation."); Editorial, End Lawyers' Shopping Spree, N.Y.DAILYNEWS.COM, Sept. 28, 2003, http://www.nydailynews.com/news/ ideas_opinions/v-pfriendly/story/121333p-109159c.html ("Who could be against this rational reform? The trial lawyers' lobby, that's who. The sharks are not about to surrender their feeding grounds. Sens. Chuck Schumer and Hillary Clinton could have a huge impact on the matter, but so far both appear happy in the role of remora."); David McDowell, President Bush Passes Class Action Fairness Act, LegAl WeEK, Mar. 24, 2005, http://www.legalweek.net/PrintItem.asp?id=23524 (noting that CAFA seeks to "curb class settlements that provide significant fees to class counsel, with marginal benefits to class members"); Editorial, Reforming Class Actions, WASH. POST, June 14, 2003, at A22 (" $[\mathrm{N}]$ o area of U.S. civil justice cries out more urgently for reform than the high-stakes extortion racket of class actions, in which truly crazy rules permit trial lawyers to cash in at the expense of business.").

${ }^{92}$ For example, Congress recently held hearings on a proposed amendment to the PSLRA, the Securities Litigation Attorney Accountability and Transparency Act (H.R. 5491), which would give judges discretion to auction off the lead counsel position in major class actions and to hold losing parties' attorneys accountable for attorneys' fees in lawsuits deemed frivolous. See Pamela MacClean, Bidding for Lead Counsel Debated, NAT'L L.J., July 17, 2006, at 5. As Representative Michael Oxley stated in support of the bill, " $[\mathrm{t}]$ he continuing prevalence of securities lawsuits manufactured by plaintiffs' attorneys for their own benefit is detrimental to companies and their shareholders. Our entire economic system ... pay[s] a high price for frivolous lawsuits that end up benefiting attorneys, not plaintiffs." See Press Release, House Comm. on Fin. Servs., Baker Panel to Advocate Transparency in Securities Litigation (June 22, 2006), available at http://financialservices.house.gov/News.asp?FormMode=release \& ID $=818$. Many view this proposed legislation as a consequence of the Milberg Weiss indictment. 
giously high." ${ }^{93}$ As the chairwoman of the FTC has publicly stated, the agency is doubtful whether these settlements "truly serve consumers' interests by providing them appropriate benefits." ${ }^{94}$ In this sharp break with prior practice, ${ }^{95}$ the agency during the second Bush administration $^{96}$ has challenged class settlements and attorneys' fees in at

${ }^{93}$ John Beisner et al., Class Action "Cops": Public Servants or Private Entrepreneurs?, 57 STAN. L. REV. 1441, 1446 (2005) [hereinafter Beisner et al., Class Action Cops]; see also Caroline E. Mayer, FTC Seeks to Limit Attorney Fees in Class Action Suits, WASH. POST, Sept. 30, 2002, at A17 (describing the FTC's challenge to attorneys' fees in several proposed class action settlements); Fed. Trade Comm'n, Legal Resources: Amicus Briefs, http://www.ftc.gov/ogc/briefs.htm (last visited Oct. 21, 2006) (providing links to FTC amicus briefs challenging class settlements and proposed attorneys' fees).

${ }^{94}$ Deborah Platt Majors, Chairwoman of the Fed. Trade Comm'n, Comments at the FTC Workshop: Protecting Consumer Interests in Class Actions (Sept. 13, 2004), in 18 GEO. J. LEGAL ETHICS 1161, 1162 (2005); see also Mayer, supra note 93, at A17 (quoting Timothy Muris, the former chairman of FTC, as saying "[o]ur job is to get more money to consumers, and by giving attorneys less, we're giving consumers more"); Press Release, Fed. Trade Comm'n, FTC's Thomas B. Leary Addresses Class Action Litigation Summit (June 26, 2003) [hereinafter FTC Press Release], available at http://www.ftc.gov/fopa/2003/06/learyspeech.htm ("The Commission has used these briefs-for example, in In re First Databank and Carter v. IRC Services-to object to excessive attorney fees, which divert needed compensation from injured consumers.").

${ }^{95}$ The FTC has a long history of filing amicus briefs in both federal and state courts on substantive areas of law within its expertise and authority. See, e.g., Stephen Calkins, The Antitrust Conversation, 68 ANTITRUST L.J. 625, 627-28 (2001) (sketching the history of FTC amicus briefs in the antitrust context). Only since 2002, however, has the agency filed briefs seeking to block private class action settlements. See Mayer, supra note 93, at A17 ("So far this year, the FTC has challenged attorneys' fees in three proposed class action settlements.”).

${ }^{96}$ The timing of this intervention led Joanne Doroshow, of the Center for Justice and Democracy, to opine that the FTC's actions seem "to dovetail with the political agenda of this administration to cut contingency fees of lawyers and discourage class lawsuits." Mayer, supra note 93, at A17. 
least six $\operatorname{cases}^{97}$ and seems poised to continue challenging fees in a host of pending cases. ${ }^{98}$

The FTC has also engaged in its own form of lobbying by urging the Judicial Conference to amend Rule 23 so as to recommend that courts "take into account the existence of related actions conducted by the government when calculating awards of attorneys fees." ${ }^{99}$ This recommendation is based on the agency's view that there exists a "substantial disparity between class counsel's fee request and class members' recovery," ${ }^{100}$ and that this disparity is particularly egregious where counsel "piggyback" on the agency's efforts. ${ }^{101}$ As an FTC official has darkly warned:

Excessive class action attorney fee awards represent a substantial source of consumer harm. Such fee awards are not a costless windfall to lawyers, but rather serve to diminish the total compensation available to injured consumers. To the extent that such fees no longer accurately reflect the amount of work performed by the lawyer, or the value of the settlement to the class, they may also create distorted incentives, thereby

${ }^{97}$ The FTC intervened in a number of cases to address attorneys' fee proposals: Schneider v. Citicorp Mortgage, Inc., 324 F. Supp. 2d 372, 378 (E.D.N.Y. 2004); In re First Databank Antitrust Litig., 209 F. Supp. 2d 96, 99 (D.D.C. 2002); Brief for Fed. Trade Comm'n as Amicus Curiae, Carter v. ICR Servs., Inc., No. CV-00-C-2666-W (N.D. Ala. Aug. 14, 2002); Intervener Fed. Trade Comm'n's Motion for Stay and Reconsideration of Order Preliminarily Approving Stipulation of Settlement and Release and Class Notice, Cass v. AmeriDebt, Inc., No. 01-CH-20350 (Cook County Cir. Ct. Ill. County Dept. Chancery Div. Mar. 23, 2004); Fed. Trade Comm'n's Memorandum of Law as Amicus Curiae, Erikson v. Ameritech Corp., No. 99-CH-18873 (Cook County Cir. Ct. Ill. County Dept. Chancery Div. June 21, 2002); Fed. Trade Comm'n's Memorandum of Points and Authorities as Amici Curiae Regarding the Proposed Class Action Coupon Settlement and Petition for an Award of Attorneys' Fees, Haese v. H\&R Block, No. CV-96-423 (Tex. Dist. Ct. June 4, 2003).

${ }_{98}$ See Beisner et al., Class Action Cops, supra note 93, at 1449 (discussing pending class action settlements in which the FTC has sought intervenor status or leave to file an amicus brief).

99 Letter from Timothy J. Muris, former Chairman, Fed. Trade Comm'n, to Peter G. McCabe, Sec'y, Comm. on Rules of Practice \& Procedure of the Judicial Conference of the United States (Feb. 15, 2002) available at http://www.ftc.gov/os/2002/ 02/rule23letter.pdf; see also Mayer, supra note 93, at A17 (indicating that the FTC has "urged the Judicial Conference ... to amend its class action rules in a way that could limit attorney fees").

${ }^{100}$ R. Ted Cruz, Dir., Office of Policy Planning, Fed Trade Comm'n, Friend of the Court: The Federal Trade Commission's Amicus Program, Remarks before the Antitrust Section of the American Bar Association 17 (Dec. 12, 2002), http:// www.ftc.gov.speeches/other/tcamicus [hereinafter Cruz Remarks].

${ }^{101}$ Id.; see also infra text accompanying notes 201-06 (discussing the overdeterrence argument in the context of piggybacking or follow-on class actions). 
promoting litigation that is not only contrary to the interests of the class, but unnecessarily raises the cost of goods and services to consumers generally. ${ }^{102}$

Taken together, the FTC's efforts to torpedo class action settlements and to amend Rule 23 to encourage limitations on attorneys' fees in class suits reveal a strongly politicized version of the compensationalist view. $^{103}$

A cynic might also point to the Justice Department's six-year probe and recent indictment on federal racketeering charges of the mega-plaintiffs' class action firm Milberg Weiss Bershad \& Schulman as the apotheosis of this politicized version of solicitude for class members. ${ }^{104}$ Whether or not the government can make out its case (and whether or not it is a case worth making out), ${ }^{105}$ the indictments have severely weakened the firm-nearly one-fifth of Milberg's partners and a significant number of its clients have left since news of the indictments broke ${ }^{106}$ - and reduced its ability to file and prosecute class actions. ${ }^{107}$

${ }^{102}$ Cruz remarks, supra note 100 , at 13 .

103 Mayer, supra note 93, at A17.

104 Press Release, U.S. Dep't of Justice, Milberg Weiss Law Firm, Two Senior Partners Indicted in Secret Kickback Scheme Involving Named Plaintiffs in Class-Action Lawsuits (May 18, 2006), available at http://www.usdoj.gov/usao/cac/pr2006/ 061.html. The indictment alleges that the firm and two named partners engaged in actions which defrauded class members, as well as the public. Id.; see also Paul Braverman, Milberg Defenders Challenge the Firm's Indictment, Left and Right, AM. LAWYER, Aug. 2006, at 17 (referencing a full-page advertisement in the New York Times that called the Milberg Weiss indictment a "cloak for the Bush administration to tear down one of our nation's most vigorous protectors of public rights" and noting that the firm had been a big donor to Democratic campaigns)

${ }^{105}$ While the indictment alleges a number of troubling incidents, it is entirely unclear why this matter cannot be handled as a state-law ethical issue, with the possibility of disbarment or other licensure-revoking penalties. In other words, why are they making a federal case out of it? See, e.g., Editorial, Very Rough Justice, WALl ST. J., May 22, 2006, at A12 (describing the Justice Department's "blunderbuss tactic of indicting the entire law firm" as "overzealous").

106 See Anthony Lin, Milberg Appointed Co-Lead Counsel in Backdating Suit, LEGAL INTELLIGENCER, July 27, 2006, at 4 ("One of the nation's leading securities plaintiffs firms, Milberg Weiss's ability to carry on with client matters has been in question since the firm and two of its name partners-David Bershad and Steven Schulman-were indicted in May on charges they paid illegal kickbacks to class action plaintiffs."); Milberg Weiss Denies \$11M Kickback Charges, LEGAL WEEK, July 27, 2006, http://www.legalweek.com/PrintItem.asp?id=29965 (recounting the firm's not-guilty plea).

${ }^{107}$ See Kate Coscarelli, 2006 Sees Sharp Drop in Class-Action Suits, STAR-LEDGER (Newark), July 28, 2006, at 51 (describing a $45 \%$ reduction in class action filings in the first 
Courts, naturally, have also responded to concerns over class compensation. ${ }^{108}$ As one court explained, in affirming a denial of attorneys' fees, "[o]ne of the drawbacks of [class action litigation] is the fact that attorneys representing the named class representatives often are well compensated, while members of the class, those who actually suffered legal injury, sometimes receive very modest or disproportionately small awards." 109 Other circuit court judges have offered the popular lament that " $[\mathrm{a}]$ ctual monetary compensation rarely reaches the class members. Concurrently, and perhaps coincidentally, such settlements are virtually always accompanied by munificent grants of or requests for attorneys' fees for class counsel."110

Finally, and predictably, the popular media have focused on the misalignment of interests and class member compensation. "Media reports of class action cases in which the lawyers received fees totaling millions of dollars while the class members received only small sums" ${ }^{111}$ have appeared with increasing frequency. ${ }^{112}$ Mass market

half of 2006 and speculating whether the Milberg Weiss indictments are a cause of the drop in filings); see also Brooke A. Masters, Investors' Class-Action Lawsuits Drop Sharply, WASH. POST, July 27, 2006, at D2 (describing a 31\% drop in securities class action suits from 2005 to 2006 and ascribing some of the drop to the fact that Milberg Weiss, "the country's largest class action firm [has] been distracted because the firm is under indictment for fraud").

${ }^{108}$ See, e.g., Patillo v. Schlesinger, 625 F.2d 262, 265 (9th Cir. 1980) (affirming a denial of class certification because "the principal beneficiaries of the class action would be plaintiffs' attorneys"); In re Ford Motor Co. Bronco II Prod. Liab. Litig., 981 F. Supp. 969, 972 (E.D. La. 1997) (rejecting a proposed settlement which would have given class members a package of safety materials and class counsel $\$ 6$ million in fees); see also James D. Cox, Compensation, Deterrence, and the Market as Boundaries for Derivative Suit Procedures, 52 GEO. WASH. L. REV. 745 (1985) (examining court decisions that seem to prioritize class compensation over the deterrence of fraudulent conduct).

${ }^{109}$ Shults v. Champion Int'l Corp., No 95-5865, 1996 WL 599824, at*2 (6th Cir. Oct. 17, 1996).

${ }^{110}$ Davis v. Carl Cannon Chevrolet-Olds, Inc., 182 F.3d 792, 798 (11th Cir. 1999) (Nangle, J., concurring); see also Beisner et al., Class Action Cops, supra note 93, at 1450 (discussing a Florida class action in which the judge reduced attorneys' fees because " $[\mathrm{t}$ ] oo often, lawyers use class actions as cash cows that ultimately don't yield much for plaintiffs" (quoting Editorial, Pay the Lawyers in Coupons, Too, ROCKY MTN. NEws (Denver), July 25, 2004, at 7E)).

${ }^{111}$ Sherman, supra note 5, at 226-27, (citing Editorial, Making Justice Work, WASH. POST, Nov. 25, 2002, at A14, which objected to settlements where class members "get token payments, while the lawyers receive enormous fees").

${ }^{112}$ See generally HENSLER ET AL., supra note 15, at 49-61 (reviewing general and business press accounts of class action litigation and concluding that these reports have grown increasingly critical over time). 
books pillorying class action lawyers are regularly published. ${ }^{113}$ Not surprisingly, then, polls indicate that a large majority of Americans do not believe class actions are socially useful. ${ }^{114}$ For example, a poll conducted by the U.S. Chamber of Commerce found that $61 \%$ of respondents believe that "consumers and class members benefit the least from the class action lawsuit system," 47\% say that plaintiffs' lawyers "benefit the most" from these suits, and $74 \%$ think that class actions "drive[] up prices and should be restrained." 115

Other polls reveal that similarly negative perceptions are shared by lawyers and judges, many of whom apparently believe that "class action plaintiffs' lawyers are overcompensated for the work that they do," particularly in cases where "class members receive in a settlement something perceived to be of little value" while "the lawyers seek and obtain what seem to be large sums of cash."116 Consumer advocates and public interest lawyers have been particularly harsh, contending that "injured consumers get less compensation than they deserve" while their lawyers get rich. ${ }^{117}$

${ }^{113}$ See, e.g., CRIER, supra note 53, at 193 ("In much of this class action litigation, the only real beneficiaries are the lawyers."); PATRICK M. GARRY, A NATION OF ADVERSARIES: HOW THE LITIGATION EXPLOSION IS RESHAPING AMERICA 12 (1997) ("Class-action lawsuits reveal the degree to which lawyers instigate and promote litigation primarily for their own benefit."); JOSEPH C. GOULDEN, THE MONEY LAWYERS: THE NO-HOLDSBARRED WORLD OF TODAY'S RICHEST AND MOST POWRFUl LAWYERS, at xiii (2006) (observing that in the class action area, "public disgust has veritably transformed the term 'trial lawyer' into something akin to a barnyard epithet").

${ }^{114}$ See, e.g., Beisner et al., Class Action Cops, supra note 93, at 1444 (referring to polls showing that "Americans do not trust the class action system, do not think that consumers benefit from class actions, and believe that lawyers take home all the money recovered in such cases"); $i d$. at 1444 n.5 (citing Darryl Haralson \& Adrienne Lewis, USA Today Snapshots: Opinions on Class-Action Lawsuits, USA TODAY, Mar. 24, 2003, at 1B).

${ }^{115}$ Press Release, U.S. Chamber of Commerce, Chamber Poll Shows Americans Want Class Action Reform: Almost Half Believe Plaintiffs' Lawyers Benefit More than Consumers (Mar. 5, 2003), available at http://www.uschamber.com/press/releases/ 2003/march/03-40.htm.

${ }^{116}$ Class Counsel Report, supra note 25, at 344. The authors also note, however, that "[1] arge recoveries get public attention, and large recoveries often result in substantial attorneys' fees that also attract attention. When class actions are dismissed, the publicity is often sparse or nonexistent, and the fact that class lawyers are uncompensated is often not understood." Id. at 6 n.13.

${ }^{117}$ HensLer ET AL., supra note 15, at 50 (citing Bob Van Voris, Plaintiff Bar Divided By Settlements: Tiny Payouts, Big Fees Hit by Public Interest Lawyers, NAT'L. L.J., Feb. 23, 1998, at A1). 
In short, with "many ordinary" and not-so-ordinary Americans now believing that the class action is a socially harmful "device invented by greedy plaintiff attorneys" ${ }^{118}$ who enrich themselves at the expense of class members, it appears that compensationalist hegemony has achieved a point of near-total saturation.

\section{Class Member Compensation as a FALSE IdOL}

The extravagant attention lavished on class member compensation and agency costs in small-claims class actions over the past twenty years has been misguided, for a number of related reasons.

Before discussing why class member compensation in small-claims class actions is irrelevant, though, it is worth pausing to ask if, indeed, "lawyers ... walk away with big baskets full of money while consumers get very little," ${ }^{119}$ as countless commentators assert.

The empirical evidence strongly suggests that class actions generate adequate compensation for claimants. An analysis of 1120 class action filings from 1990 to 2003-the most thorough study of its kind, undertaken by Class Action Reports-found that "for every dollar recovered in a common fund class action, 18.4 cents goes to the attorneys and for other costs (expert fees, out-of-pocket expenses, etc.) and 81.6 cents goes to the class members." ${ }^{120}$ Surely, as the study's authors concluded, 81.6 cents on the dollar "should seem to be a pretty good deal for class members relative to paying, say, $40 \%$ to an individual personal injury lawyer."

Another study of class actions in four federal districts, conducted by the Federal Judicial Center (FJC), "did not show recurring situations where [Rule 23] (b) (3) actions produced nominal class benefits in relation to attorneys' fees." ${ }^{122}$ While the FJC study closely analyzed

\footnotetext{
${ }^{118}$ Deborah R. Hensler, Revisiting the Monster: New Myths and Realities of Class Action and Other Large Scale Litigation, 11 DuKE J. COMP. \& INT'L L. 179, 180 (2001).

119 Todd Zywicki, Professor, George Mason Law School, Comments at the 2005 FTC Workshop: Protecting Consumer Interests in Class Actions (Sept. 13, 2004), in 18 GEO. J. LEGAL ETHICS 1289, 1291 (2005) [hereinafter Zywicki Comments].

${ }_{120}$ Attorney Fee Awards in Common Fund Class Actions, 24 Class ACTION REPS. 167 (2003); see also Theodore Eisenberg \& Geoffrey P. Miller, Attorneys' Fees in Class Action Settlements: An Empirical Study, 1 J. EMP. LEGAL STUD. 27, 27 (2004) (evaluating data from two studies of class action fee awards over a nine-year period).

${ }^{121}$ Attorney Fee Awards in Common Fund Class Actions, supra note 120, at 167.

${ }^{122}$ Thomas E. Willging et al., Empirical Study of Class Actions in Four Federal District Courts: Final Report to the Advisory Committee on Civil Rules 77 (1996) available at http://www.fjc.gov/ public/pdf.nsf/lookup/rule23.pdf/\$File/rule23.pdf\#search='optouts\%20class\%20actions'.
} 
cases in which "the settlement produced relatively small payments to the class," including nine cases where the average compensatory award per class member was less than $\$ 100$, the authors concluded that there was no evidence that these cases failed to produce meaningful aggregate benefits. ${ }^{123}$ They also found attorneys' fees in cases with small per-plaintiff recoveries directly correlated with aggregate class compensation. ${ }^{124}$

But even if we were to ignore the empirical data-even if we were hell-bent on making policy decisions based upon anecdotes of high fees and low aggregate pay-outs-we would still be barking up the wrong tree because, in fact, class member compensation just does not matter in the vast majority of small-claims class actions.

\section{A. Why Compensation Just Does Not Matter}

The vast majority of consumer class actions are low-value claims in which the amount at stake for each plaintiff is small. ${ }^{125}$ There is a dearth of reliable data on the average per-plaintiff value of smallclaims consumer class actions, but anecdotal evidence suggests that these claims very often concern less than $\$ 100$ per plaintiff. ${ }^{126}$ In any

123 Id.

${ }^{124}$ Id. at 14, 160-61.

${ }^{125}$ See Class Counsel Report, supra note 25, at 347 (“[B] ecause the common fund class action is designed to pool a number of small claims, many members of the class do not know and may not care about the litigation."); Macey \& Miller, supra note 2, at 30 ("In the large-scale, small-claim class action context . . the claims of the individual class members are very small.").

${ }^{126}$ Two well-cited studies peg average per-plaintiff values at more than $\$ 100$. For example, Professor Hensler's RAND study of ten consumer class actions found that "alleged individual dollar losses" ranged from $\$ 3.00$ in an insurance premium doublerounding case to $\$ 4500$ in a brokerage products case. But, as the author is correct to note, "averages can be deceptive," and "it is a matter of judgment whether alleged losses to individuals are "trivial' ... or not so trivial." HENSLER ET AL., supra note 15, at 419-20. Similarly, an FJC study found the median level of recovery per class member to range from $\$ 315$ to $\$ 528$ across the four districts studied. Willging et al., supra note 122, at 7. Anecdotally, however, it seems that the average dollar value per class member in small-claims class actions is probably far lower than either of these studies indicates. See, e.g., HENSLER ET AL., supra note 15, at 81 (discussing the "widely reported settlement of a 1980s class action lawsuit against Levi Strauss \& Co., [in which] an estimated 7 million households were eligible to collect a maximum of $\$ 2.00$ per pair of blue jeans purchased"); Macey \& Miller, supra note 2, at 30 (providing the example of $\$ 70$ per-plaintiff claims at issue in Eisen v. Carlisle, 417 U.S. 156, 161 (1974)); Stephen E. Frank, First USA Settles Cardholder Suit Alleging It Switched Interest Rates, WALL ST. J., Sept. 4, 1997, at B8 (discussing a proposed class action settlement based on allegedly 
event, we certainly assume that the average per-plaintiff stake in a consumer class action case is sufficiently low that most people would not go to much bother to seek compensation. ${ }^{127}$

And, in fact, most people do not bother. For one thing, very few people exercise their right to commence separate litigation as optouts. Two separate studies have concluded that the opt-out rate in consumer class actions is, on average, less than $1 \%$ of the total class membership. ${ }^{128}$ Further, the rate at which opt-outs actually commence separate litigation likely is even lower. This is all the more significant since class members and class counsel effectively subsidize opt-outs, who are able to free-ride on the litigation work of class counsel, are relieved of litigating often difficult class certification issues, and only have to prove their own damages. ${ }^{129}$

misleading credit card solicitations in which plaintiff cardholders would receive a maximum of $\$ 3.85$ each).

${ }^{127}$ Macey \& Miller, supra note 2, at 28 (asserting that "[i]n the large-scale, smallclaim class action .... [m] ost plaintiffs are unlikely to place any significant value" on notice). Macey and Miller explain:

Upon receiving and reading notice of the suit, the typical plaintiff in a largescale, small-stakes class action has a choice between two courses of action. She can do nothing, in which case she will receive a check in the mail if the suit is successful and will incur no costs if the suit fails. Or she can go to the trouble of opting out of the action, in which case she will receive nothing whether or not the suit is successful. Such a decision is not hard to make. Nearly everyone who understands the nature of this choice will elect to do nothing and thereby remain part of the class action.

Id. (footnotes omitted).

${ }^{128}$ See Theodore Eisenberg \& Geoffrey P. Miller, The Role of Opt-Outs and Objectors in Class Action Litigation: Theoretical and Empirical Issues 4 (N.Y.U. Law \& Econ. Research Paper Series, Working Paper No. 04-004, 2004), available at http://papers.ssrn.com/ sol3/papers.cfm?abstract_id=528146 (finding that, "on average, less than one percent of class members opt-out and about one percent of class members object to class-wide settlements," with the lowest numbers of opt-outs in consumer class actions); Willging et al., supra note 122, at 10, 135 (finding that "the median percentage of members who opted out of a settlement was either $0.1 \%$ or $0.2 \%$ of the total membership of the class; $75 \%$ of the opt-out cases had $1.2 \%$ or fewer of class members opt out"; and that nearly $56 \%$ of the class actions studied had not one single opt-out).

${ }^{129}$ See Rosenberg, supra note 55, at 30-31 (assuming that opting out "affords class members the opportunity to exit before class trial or settlement of the common questions without bearing any obligation to pay the full pro rata share of class counsel's fee for prosecuting the class claim on the common questions"); id. at 35 ("Class counsel will reduce the collective investment in light of the lower net return resulting from free riding opt-outs, thereby undermining optimal deterrence to make everyone worse off ex ante."). 
But even if opt-out rates were high, the fact is that class members-by definition-have elected not to opt out. The compensationalists lavish their concern on the people who have decided that it is not worth their time and bother to pursue their claims for compensation, notwithstanding the subsidized opportunity offered them by the opt-out notice. If the amount at issue was worth chasing, the plaintiff could have opted out. ${ }^{130}$

Of course, it is possible that the plaintiff was not aware of her optout right. ${ }^{131}$ But that would be the case only if her stake were so low that she could not be bothered to read the notice material that informed her of the claim. ${ }^{132}$ After all, the opt-out notice is generally the first notification that the class member receives that a claim even exists. If the class member's stake is so low that it is not worth her time to read the notice, we find that perfectly understandable. ${ }^{133}$ Less

130 Hensler notes:

If the loss is large and apparent to the individual consumer or business, that party may seek legal advice and, eventually, bring an individual lawsuit. But if the loss is small, it is less likely to be recognized by those affected, and it is less likely that anyone will come forward to claim compensation even if many individuals or businesses are affected by it. Most individuals are too preoccupied with daily life and too uninformed about the law to pay attention to whether they are being overcharged or otherwise inappropriately treated by those with whom they do business. Even if they believe that there is something inappropriate about a transaction, individuals are likely just to "lump it," rather than expend the time and energy necessary to remedy a perceived wrong.

HENSLER ET AL., supra note 15, at 68 (citation omitted).

${ }^{131}$ In some scenarios, individuals with high-value claims must opt out (or else be kicked out) of the class action because their claims differ from those of the class and threaten the commonality required for certification. See, e.g., Zywicki Comments, supra note 119, at 1295 (observing that, where individual class members have high-value claims, "chances are [that] interests diverge, usually the [individual] case will differ [from the class claims], and maybe people should be getting individual representation").

${ }^{132}$ See, e.g., John Bronsteen \& Owen Fiss, The Class Action Rule, 78 NOTRE DAME L. REV. 1419, 1420 (2003) ("Consumed with matters that impinge on ordinary life, most people throw out notice letters without reading them, much less understanding them."); Macey \& Miller, supra note 2, at 28 (describing the rational response of the small-claims consumer upon receiving an opt-out notice for a claim she never even realized she had as "do[ing] nothing")

${ }^{133}$ Some commentators suggest that the failure of class members to opt out or assert claims upon settlement is due to confusing notices or an overwhelming volume of mail, rather than to mere indifference. See, e.g., Pamela Jones Harbour, Commissioner, Fed. Trade Comm'n, Comments at the 2005 FTC Workshop: Protecting Consumer Interests in Class Actions (Sept. 13, 2004), in 18 GEO. J. LEGAL ETHICS 1161, 1290 (2005) (" $[\mathrm{I}] \mathrm{n}$ the modern day era of mass communications where most consumers face overflowing email or snail mail, we need ... to craft and ... distribute class 
understandable is why we should be concerned with her compensation.

We wholeheartedly agree with critics such as Coffee, Redish, Macey, and Miller who argue that the overwhelming majority of consumer class actions are lawyer-initiated and lawyer-driven: the claims are developed by lawyers who then present the litigation opportunity to individuals or entities with standing to sue. ${ }^{134}$ This recognition, however, supports our argument, not the argument of the compensationalists: we, too, would be concerned with compensation if injured plaintiffs, seeking monetary redress, banded together and approached a plaintiffs' lawyer to press their claims in a class action. ${ }^{135}$ But that is not how small-claims class actions work, as these scholars remind us.

Further, our theory that compensation in small-claims class actions does not matter would be significantly undermined if we believed that consumers, at the time of contracting, attached any meaningful value to the right to someday seek compensation in a class action. $^{136}$ If they did, rules that diminish or eliminate compensation rights would have economic repercussions; they would affect consumer conduct. But we don't think consumers would do anything differently if their right to receive money in a 23(b) (3) class action were eliminated altogether. We doubt that a single sale would be lost or diverted. $^{137}$ By contrast, if individuals could not sue for damages, they

notices that won't inadvertently be thrown out by consumers or deleted as junk mail.”). We think, however, that if the amount of damages at issue is sufficiently important to the recipient of the notice, she might take the time to open the mail, read the notice, and establish her stake in the settlement.

${ }^{134}$ See supra note 52 and accompanying text (describing the leading role of attorneys in every stage of class action litigation).

${ }_{135}$ Cf. HENSLER ET AL., supra note 15, at 403-06 (describing consumer class actions in which individuals contacted attorneys seeking representation). Hensler cites the Pinney v. Great Western Bank litigation, which started after "hundreds of Great Western brokerage products purchasers" contacted an attorney, who then "invited attorney friends with employment law and civil rights experience to join him in a class action" against the defendant. Id. at 404-05.

${ }^{136}$ See Gilles, Opting Out of Liability, supra note 12, at 427 (rejecting the possibility that, at the time of contracting, consumers and other putative class plaintiffs place any value on the ability to seek damages via the class action device).

${ }^{137}$ On a related note, David Rosenberg explains that, if given a choice, most people would

select a [legal] system that prioritized optimal deterrence over compensating loss from otherwise preventable unreasonable risk, or any other litigationrelated interest, such as personal control over the prosecution of claims. These conclusions reflect the overwhelming evidence of peoples' revealed 
might not contract to buy a house, or visit a particular doctor, or take any of a million different actions. ${ }^{138}$ At work here are two related points: (1) the right to seek compensation ceases to be meaningful (viewed ex ante) when the value of the potential claim is low; and (2) the right to receive money damages as part of a class is far less likely to be meaningful, ex ante, than the right to sue for damages.

\section{B. Empirical Support from Securities Fraud Class Action Analysis}

We draw further support here from empirical work done by certain scholars in the area of securities class actions. According to a study by James Cox and Randall Thomas of 118 securities class action settlements, institutional investors in these cases suffered an "average mean loss" of almost $\$ 850,000$, and an "average median loss [of] roughly $\$ 275,000$." 139 With losses of this degree, one might think that class members would evince some concern with obtaining compensation.

The Cox and Thomas study, however, tells a dramatically different story: on average, "approximately seventy percent of the institutions with provable losses fail to present their claims" in response to notices-often repeated notices-from settlement fund claims administrators. ${ }^{140}$ The study also found that institutional investors fail to es-

and expressed preferences and follow logically from the proposition that efficient reduction of accident costs increases the individual's expected net welfare across all possible states of the world.

Rosenberg, supra note 55, at 26 (internal citations omitted).

${ }^{138}$ Perhaps unfairly, we will pick on a student note-writer here, who writes that "[i]f individuals had no means of redress for their small claims, they would likely lose faith in the marketplace ...." Ilana T. Buschkin, Note, The Viability of Class Action Lawsuits in a Globalized Economy: Permitting Foreign Claimants To Be Members of Class Action Lawsuits in the U.S. Federal Courts, 90 CORNELL L. REV. 1563, 1585 (2005). If the writer means that consumers would be disheartened in a general sense if there were no class action deterrent, we agree. If she means that consumer behavior is related to the ability to recover on small claims, her argument is belied by the evidence.

${ }^{139}$ Cox \& Thomas, supra note 83, at 424.

${ }^{140} I d$. at 450 . Earlier studies revealed similarly low claim rates by large institutional investors. For example, in analyzing data provided to the Senate Securities Subcommittee by Gilardi \& Co., a leading claims administrator, Weiss and Beckerman found that "the fifty largest claimants in eighty-two actions accounted for a median of $57.8 \%$ and an average of $57.5 \%$ of all allowed losses, even though they represented only a median of $1.7 \%$ and an average of $3.5 \%$ of all claims filed." Weiss \& Beckerman, supra note 3, at 2089. They also found that "the fifty largest claimants' average loss was $\$ 597,000$ in the eighty-two actions for which all necessary data were reported; their median loss was $\$ 267,927$. In fifteen of those actions, the fifty largest claimants' aver- 
tablish systems for the submission or monitoring of claims filings. ${ }^{141}$ The data suggest that these investors, not unlike their consumer counterparts, simply cannot be bothered to take any affirmative action to recover funds from class settlements. ${ }^{142}$

Professor A.C. Pritchard argues that these results are not surprising. Analyzing the Cox and Thomas data, along with other public information, Pritchard makes a ballpark assessment that the unclaimed losses of these institutional investors represent only " $0.087 \%$ of assets under management," adding that "most people-including the institutions ignoring class action settlements-would consider $0.087 \%$ to be in the range of a rounding error." ${ }^{143}$ While one might argue that assets under management is not a fair measuring stick-that market cap or some other gauge of net worth is more appropriate-the point remains the same: the amounts at stake in securities class action settlements are so low that institutional investors do not feel compelled to file claims. ${ }^{144}$ Not surprisingly, Pritchard surmises that "[n]o reasonable investor considering where to allocate his savings... would take into account the availability of class action settlements." 145

Of course, it is one thing to say that institutional investors are uninterested in submitting claims forms to recover losses totaling less than $0.1 \%$ of their assets under management (or, say, $1 \%$ of net

age allowed loss exceeded \$1 million.” Id.; see also Janet Cooper Alexander, The Value of Bad News in Securities Class Actions, 41 UCLA L. REv. 1421, 1449 (1994) (asserting, based on a review of securities class action settlements, that "a substantial number of shares-perhaps $40 \%$ or more-do not file claims").

${ }^{141}$ See Cox \& Thomas, supra note 83, at 445 ("[The] majority of our survey respondents did very little monitoring of their custodians or advisors to determine if they were forwarding settlement notices and, for those contracting out claims filing services, filing claims.").

${ }^{142}$ That institutional investors fail to make claims upon settlement of securities class action suits is all the more surprising given that these plaintiffs are "sophisticated and well-informed members" of the business world who often compete at the beginning of a class action "for the position of lead plaintiff" or contest "the settlement's fairness or the reasonableness of the attorney's fees" at the end of the litigation. Coffee, Securities Class Action, supra note 1, at 8-9.

${ }^{143}$ A.C. Pritchard, Who Cares?, 80 WASH. U. L.Q. 883, 883-84 (2002).

${ }^{144}$ See $i d$. at 884 ("It seems unlikely that such a small percentage would make a difference in the competition to attract investors. Perhaps money managers have more important things to worry about. For example, money managers may spend their time investigating companies so as to avoid investing in fraudulent firms.").

${ }^{145} I d$. Pritchard's point lines up nicely with our argument that consumers, at the time of contracting, do not attach any meaningful value to the right to someday seek compensation in a class action. See supra text accompanying notes 136-38 (concluding that consumers do not value the possibility of future class action damages). 
worth), and perhaps another to expect similar behavior from individual consumers. And yet, the median household net worth in the United States in 2000 was valued at $\$ 55,000,{ }^{146}$ so that the average perplaintiff damage value in a typical consumer class action amounts to between $.1 \%$ and $.3 \%$ of household net worth. ${ }^{147}$ Given these numbers, should we really be surprised if individual consumer class members ignore claims forms at an even higher rate than their institutional counterparts? ${ }^{148}$

\section{The Efficiency Myth}

Just as it distorts matters to evaluate class action rules through the prism of class member compensation, so too is it unfruitful to use administrative efficiency as a guidepost. Efficiency, in this context, refers to the reduction of the time and expense of adjudicating a multiplicity of factually similar suits. ${ }^{149}$

The fact of the matter is that in small-claims cases, the class action device does not promote administrative efficiency at all. It brings cases into the system that would otherwise never have been brought. It does not save time or money; it costs time and money. The common misconception is that the alternative to the class action is thou-

${ }^{146}$ U.S. CENSUS BUREAU, U.S. DeP'T OF COMMERCE, NeT WORTH \& ASSET OWNERSHIP OF HOUSEHOLDS: 1998 \& 2000, at 2 (2003), available at http://www.census.gov/ $\operatorname{prod} / 2003$ pubs/p70-88.pdf.

${ }^{147}$ See supra notes 125-27 and accompanying text (discussing the likely per-plaintiff values at stake in small-claims class actions).

${ }^{148}$ Some anecdotal evidence suggests that consumers regularly fail to make claims for recovery from class funds. See, e.g., HENSLER ET AL., supra note 15, at 81 (asserting that attorneys for both sides "do not know precisely how many [class members] will come forward to claim their share of the settlement"). Hensler notes that in the Levi Strauss settlement, "somewhere between 14 and 33 percent of all eligible consumers filed claims" seeking compensation from the settlement fund, while "in a 1988 suit against Wells Fargo, less than 5 percent of eligible account holders came forward to claim refunds"). Id. Moreover, in three of the six consumer class actions studied, "class members claimed less than half of the funds set aside for compensation," and only about $30 \%$ to $35 \%$ of these funds were ultimately collected. Id. at 429 .

${ }^{149}$ See FED. R. CIV. P. 23 (b) (3) advisory committee's note ("Subdivision (b) (3) encompasses those cases in which a class action would achieve economies of time, effort, and expense ...."); cf. HENSLER ET AL., supra note 15, at 49 ("Is the Rule 23(b) (3) class action primarily an administrative efficiency mechanism, a means for courts and parties to manage a large number of similar legal claims, without requiring each litigant to come forward and have his or her claim considered individually?"). 
sands of individual claims. ${ }^{150}$ But in the typical consumer case, the alternative is no case at all. ${ }^{151}$

In sum, neither class member compensation nor administrative efficiency is a useful normative polestar for evaluating the rules and practices surrounding small-claims class actions. The interjection of these concepts only distracts from the appropriate focus of any such examination, which ought to be-singularly-upon the value of deterrence.

\section{EXAmining Class Action Rules AND Practices Through THE ONE TRUe LENS OF DETERRENCE}

We assert that the primary goal in small-claims class actions is deterrence, and that the only question we should ask with respect to any rule or reform proposal in this area is whether it promotes or optimizes deterrence. Once we abandon our obsession with agency costs and windfall fees, discard our compensationalist lenses, and pledge fealty to the one true value of compelling corporate defendants to internalize the social costs of their actions, everything takes on a new light. An examination of some of the hot-button issues in the class action arena bears this out.

\section{A. Reexamining Attorneys' Fee Rules}

As discussed above, the lodestar cross-check has been almost universally adopted by courts to ensure "that plaintiffs' lawyers are not receiving an excessive fee at their clients' expense." ${ }^{152}$ The dominant

${ }^{150}$ See, e.g., HENSLER ET AL., supra note 15, at 49-50 (observing that because class actions require "telling people that they may have a claim of which they were previously unaware ... virtually every damage class action has the potential to expand the pool of litigants beyond what it would have been without class litigation").

${ }^{151}$ The analysis shifts where the class is made up of individuals with high-value claims. As one commentator has noted:

The efficiency objective is less applicable to small-claim securities, antitrust, and consumer class actions. In these cases, the losses sustained by individual investors and consumers are rarely large enough to justify independent lawsuits .... After all, from a pure efficiency standpoint, a class action certainly imposes greater burdens upon the court and upon corporate defendants than no suit at all.

Buschkin, supra note 138, at 1584 .

${ }^{152}$ Gunter v. Ridgewood Energy Corp., 223 F.3d 190, 199 (3d Cir. 2000); see also supra text accompanying note 64 (discussing various authors' concerns with the potential for "windfall" attorneys' fees under a percent-of-fund method). 
sentiment is summed up in the title of District Judge Vaughn Walker's article The Ethical Imperative of a Lodestar Cross-Check: Judicial Misgivings About "Reasonable Percentage" Fees in Common Fund Cases. ${ }^{153}$ In that article, Judge Walker and his coauthor propose that courts "should as a matter of course perform a lodestar cross-check" to ensure that "common funds will not be depleted by unreasonably high attorney fee awards computed using the percentage method." 154 Nonetheless, the demonstrable reality is that the vaunted lodestar cross-check ensures suboptimal deterrence.

\section{The Lodestar Cross-Check Caps Deterrent Value}

If we accept the premise that class-action plaintiffs' lawyers are entrepreneurial agents who will act in their own best economic interests, ${ }^{155}$ then we have to accept that the lodestar cross-check caps settlements, often at grossly suboptimal levels.

A hypothetical will illustrate this point. Suppose that a defendant has $\$ 1$ billion in potential liability (i.e., after a trial), and that the plaintiff class has a $75 \%$ chance of winning the case, having survived various dispositive motions and won its motion to certify the class. Suppose further that the plaintiffs' lawyers know that, at most, they can generate a lodestar of $\$ 5$ million preparing for trial, ${ }^{156}$ and that the highest multiplier this jurisdiction ever awards on a lodestar is $4 x$-i.e., four-times-lodestar. ${ }^{157}$ Now, if the defendants put a settle-

${ }^{153}$ Walker \& Horwich, supra note 68.

${ }^{154} I d$. at 1470 .

${ }^{155}$ See Bruce L. Hay, Asymmetric Rewards: Why Class Actions (May) Settle for Too Little, 48 HASTINGS L.J. 479, 481-82 (1997) (asserting that, in some cases, class counsel "has an incentive to settle the case for a miniscule fraction of its value to the class"); see also Geoffrey P. Miller, Payment of Expenses in Securities Class Actions: Ethical Dilemmas, Class Counsel, and Congressional Intent, 22 REV. LITIG. 557, 580 (2003) (describing class settlement as the moment "when class counsel may face a tradeoff between counsel fees and relief for the class").

${ }^{156}$ See infra text accompanying notes 169-78 (discussing lodestar generation).

${ }^{157}$ Recall that the lodestar cross-check requires courts to check a percent-of-fund award against a lodestar. The court calculates the lodestar by multiplying hours expended by a reasonable fee. It then applies to the lodestar a "multiplier" to account for the risk and quality of work by class counsel. See supra text accompanying note 65 . The multipliers generally range from $1 x$ to $5 x$ the lodestar amount. See Attorney Fee Awards in Common Fund Class Actions, supra note 120, at 167 (examining 1120 class actions over a thirteen-year period and finding that multipliers in these cases ranged from 1.10 to 4.50 ); Walker \& Horwich, supra note 68, at 1472 ("In our informal review, the multipliers ranged from about 1.0 to over 5.0, with a substantial number of multi- 
ment offer on the table for $\$ 100$ million, what can we expect the plaintiffs' lawyers to do?

Acting as independent entrepreneurs in their own economic selfinterest, the lawyers will settle a $\$ 1$ billion case (or, on an expected value analysis, a $\$ 750$ million case ${ }^{158}$ ) for $\$ 100$ million. At $4 x$-lodestar, the maximum attorneys' fee allowable under a lodestar cross-check is $\$ 20$ million. If courts award attorneys' fees of approximately $25 \%$ of the common fund, ${ }^{159}$ subject to cross-checking, then the court can be expected to award that $\$ 20$ million fee on any settlement of $\$ 80$ million or more. So even if the lawyers were to procure a $\$ 750$ million settlement, they would still "only" receive the $\$ 20$ million fee, as opposed to the $\$ 187.5$ million they could expect in a pure percent-offund regime. In a lodestar cross-check world, there is simply no incentive to expend any additional effort, or take any additional risk, to increase the amount of the recovery much over $\$ 80$ million. ${ }^{160}$

Because the true settlement value of the case is $\$ 750$ million, it might seem a pretty safe bet that some brinksmanship-for example, picking a jury and beginning a trial-would unlock hundreds of millions of incremental settlement dollars from the defendant. But our rational entrepreneurial lawyer will not take that risk. ${ }^{161}$ Her incentive

pliers in the 3.0 to 4.0 range.”); see also Patricia M. Hynes, Plaintiffs' Class Action Attorneys Earn What They Get, 2 J. INST. FOR STUDY LEGAL ETHICS 243, 245 (1999) (referencing an empirical study by two Harvard economists in the early 1990s that concluded that class actions were "economically impractical if the anticipated fee multiplier... upon successful conclusion of the case was no higher than two, even if the likelihood of success in the case was $70 \%$ ").

${ }^{158}$ The "true" settlement value of the case, on an expected value model, is $\$ 750$ million where there is a $75 \%$ chance of winning $\$ 1$ billion at trial.

159 See Casey, supra note 40, at 1279 ("'District courts across the nation . . a apparently eased into a practice of "systematically" awarding fees in the $25 \%$ range, "regardless of type of case, benefits to the class, numbers of hours billed, size of fund, size of plaintiff class, or any other relevant factor."'”) (quoting Goldberger v. Integrated Res., Inc., 209 F.3d 43, 51 (2d Cir. 2000)); Walker \& Horwich, supra note 68, at 1457-58 (noting that courts typically award fees somewhere between $25 \%$ and $30 \%$ of the fund under the percent-of-fund approach).

${ }^{160}$ Of course, this model is based on a maximum pre-trial lodestar, and an additional lodestar is generated by trying a case. However, the marginal increase in lodestar through a trial is rarely a serious consideration, given the extraordinary risk posed by virtually any trial. And again, the lawyers' huge downside risk is not offset by any commensurate prospect of upside returns where the lodestar cross-check is in effect; instead, the only offsetting benefit is some marginal increase in lodestar.

${ }^{161}$ See, e.g., Macey \& Miller, supra note 2, at 22 ("Plaintiffs' attorneys may ... wish to settle ... on the eve of trial, knowing that in so doing they obtain most of the benefits they can expect from the litigation while eliminating their downside risk."); 
to settle caps out at around $\$ 80$ million. She will want to exceed that number somewhat-to build in a cushion of $25 \%$ or so ${ }^{162}$-for a real "settlement-incentive breakpoint" of $\$ 100$ million. Accordingly, the defendant's offer will serve her interests.

As this hypothetical shows, the lodestar cross-check may "protect" class members against windfall attorneys' fees, but it seriously undermines the value of deterrence, aligning incentives to cap the amount of social costs the corporate wrongdoer is forced to internalize. And it does this in every case that warrants our concern. The only instances where the lodestar cross-check does not cap settlement amounts are cases where the lodestar method would produce a higher fee than the percent-of-fund approach. But in such cases there is nothing to crosscheck the fee against, and courts will simply apply the percent-of-fund approach.

\section{a. Why Do Compensationalists Favor Cross-Checks?}

One would think that compensationalists too might embrace this critique of the lodestar cross-check. After all, on the above hypothetical, a straight percent-of-fund approach would have produced not only a greater overall deterrence wallop ( $\$ 750$ million versus $\$ 100$ million), but also a higher net recovery for class members $(\$ 562.5$ million ${ }^{163}$ as opposed to $\$ 80$ million). But they do not embrace it, and we think there are several reasons why.

In cases where the true settlement value of a case is relatively close to the lawyers' "settlement-incentive breakpoint" (where the lawyers

\footnotetext{
Manesh, supra note 47, at 935 ("Even though he knows that more time spent in negotiation, and perhaps litigation, could yield a larger recovery for his clients, the class counsel may realize that the additional time invested would not be worth the additional fees-it would reduce his hourly compensation.").

${ }^{162}$ The $25 \%$ cushion reflects the fact that neither the average percentage award (here, 25\%) nor the average lodestar multiplier (here, $4 x$-lodestar) is likely set in stone. The cushion protects against a lower-than-normal percent award (class counsel might as well get the settlement up because the court may award only $20 \%$ instead of a standard $25 \%$ ) and positions the lawyer to benefit from a higher multiplier (if the court awards $5 x$-lodestar, and class counsel has based its breakpoint on an assumption of $4 x$-lodestar, she would be leaving money on the table). See, e.g., Macey \& Miller, supra note 2, at 52 ("Plaintiffs' attorneys have little means for predicting how many of their hours the judge will allow [under the lodestar approach], other than guesses based on the trial judge's reputation as 'tough' or 'lenient' on fees.").

${ }^{163}$ We are assuming settlement at the true value of $\$ 750$ million and a pure 25 percent-of-fund attorneys' fee.
} 
will settle out of self-interest) ${ }^{164}$ the lodestar cross-check will often yield a higher class member compensation but lower overall settlement amount than a pure percent-of-fund approach. For example, if the true settlement value in our hypothetical were $\$ 105$ million, then the class member compensation would be higher under a lodestar cross-check, even though the overall settlement would be lower. The following tables reflect this calculus (all terms and assumptions are defined in the footnote, and all dollar values are in millions) $:{ }^{165}$

${ }^{164}$ Again, the "settlement-incentive breakpoint" is the lowest settlement number that will yield the attorney her maximum fee, which is capped by the lodestar crosscheck.

${ }^{165}$ The term "maximum fee" refers to $4 x$-lodestar; percent-of-fund awards are presumed to be $25 \%$; and the "settlement-incentive breakpoint" is the lowest settlement number that will yield the max fee after factoring in the $25 \%$ cushion described above. See supra note 162. 
Table 1: Lodestar Cross-Check

\begin{tabular}{lrc} 
& Scenario 1 & Scenario 2 \\
\hline \hline True Value & 750 & 105 \\
Lodestar & 5 & 5 \\
Maximum fee & 20 & 20 \\
Breakpoint & 100 & 100 \\
(with cushion) & 100 & 100 \\
Settlement & 20 & 20 \\
Fees & 80 & 80 \\
Class members' & & \\
compensation & &
\end{tabular}

Table 2: Percent-of-Fund

\begin{tabular}{lcc} 
& Scenario 1 & Scenario 2 \\
\hline \hline True Value & 750 & 105 \\
Lodestar & $\mathrm{n} / \mathrm{a}$ & $\mathrm{n} / \mathrm{a}$ \\
$\begin{array}{l}\text { Maximum fee } \\
\text { Breakpoint } \\
\text { (with cushion) }\end{array}$ & $\mathrm{n} / \mathrm{a}$ & $\mathrm{n} / \mathrm{a}$ \\
Settlement & 750 & $\mathrm{n} / \mathrm{a}$ \\
$\begin{array}{l}\text { Fees } \\
\text { Class members }\end{array}$ & 187.5 & 105 \\
compensation & 562.5 & 26.25 \\
\hline
\end{tabular}

Table 3: Which System Benefits the Value of...

\begin{tabular}{ccc}
\hline \hline Value & $\mathbf{\$ 7 5 0 M}$ value case & $\mathbf{\$ 1 0 5 M}$ value case \\
& $\begin{array}{cc}\text { Percent-of-fund } \\
(750 \text { versus } 100)\end{array}$ & $\begin{array}{c}\text { Percent-of-fund } \\
(105 \text { versus } 100)\end{array}$ \\
Deterrence? & Percent-of-fund & $\begin{array}{c}\text { Lodestar cross-check } \\
(80 \text { versus } 78.75)\end{array}$ \\
Class & $(562.5$ versus 80$)$ & \\
\hline
\end{tabular}


So, the compensationalists' enthusiasm for cross-checking might reside in empirical intuitions about whether true settlement values tend to lie close to the settlement-incentive breakpoints of entrepreneurial class lawyers, or the frequency with which class compensation will indeed be enhanced in a cross-checking regime. Or perhaps the reason is rooted in an aversion to windfall profits for plaintiffs' lawyers. That aversion could be either moral or instrumental. One might argue that allowing plaintiffs' lawyers to make too much money will lead to too many class filings, or drive too many lawyers into the class action business. But none of that, in truth, matters if we adopt the value of deterrence as our normative polestar.

\section{b. Deterrence Abhors a Cross-Check}

Once we have accepted that the only pertinent value is forcing defendants to internalize the social costs of their actions, there is only one line item that matters: aggregate settlements. Nothing else matters-not "windfalls," not class compensation, and certainly not ratios of attorney fees to lodestars or settlement values.

Any disunity between "true" settlement values and actual settlements represents a simple deficit (or surplus) of deterrence. The differential between lawyers' settlement-incentive breakpoints and true settlement values represents a gulf of inefficiency.

It is worth considering whether empirical testing might bear out the hypothesis that a pure percent-of-fund regime will yield higher settlements, over time and across like cases, than a lodestar cross-check regime. ${ }^{166}$ We are somewhat skeptical, however, that credible data can be obtained. Even if there was a sufficiently large data set controlling for all of the many variables at play, the results would not be meaningful unless we were assured that the lawyers knew in advance that the court would award fees on a pure percent-of-fund basis, without regard to lodestar. The lodestar works its dark magic not on a case-bycase basis, but rather jurisdiction-by-jurisdiction. If a court sometimes

${ }^{166}$ The closest we have seen to an analysis of this sort was conducted by the authors of Attorney Fee Awards in Common Fund Class Actions, supra note 120, at 167, finding that in cases using the percent-of-fund approach, attorneys received approximately $21 \%$ of the fund, while in cases using the lodestar or lodestar cross-check approach they received approximately $14.5 \%$ of the fund. Needless to say, such data do not illuminate the question of whether-everything else being equal-a pure percent-offund regime will produce higher settlements. 
employs a lodestar cross-check, then self-interested entrepreneurial lawyers will conduct their affairs accordingly. ${ }^{167}$

2. Under the Current, Perverse Regime, Unethical Bill-Padding Actually Benefits Class Members

Another value trumpeted in the traditional compensationalist/agency-cost/anti-windfall critique is the avoidance of high agency costs in the form of padded bills, "churned" hours, overstaffed cases, and generally wasteful attorney practices. ${ }^{168}$ Here again, the traditional view is off-base.

The perverse and subversive reality is that, under the current regime, all of this bill-padding, document-churning and so forth are good things, both for class member compensation and deterrent values. Here is why: Suppose that the lawyers in our previous hypothetical (the one with the $\$ 750$ million settlement value) were able, through otherwise unproductive activity, to increase their lodestar from $\$ 5$ million to $\$ 8$ million. The settlement math then plays out differently. The lawyers understand that, at $4 x$-lodestar, their maximum fee is probably $\$ 32$ million, no matter how large the fund they create. They also understand that under the percent-of-fund method, the court would likely award no more than $25 \%$ of the common fund as a fee. Thus, the initial breakpoint at which the lawyers will settle is $\$ 128$ million; adding the $25 \%$ cushion, as before, results in a "settlement-incentive breakpoint" of $\$ 160$ million. While the lawyers have no incentive to push beyond $\$ 160$ million, they have increased the overall fund (and the overall punishment visited upon the defendant) by $\$ 60$ million, as reflected in the table:

${ }^{167}$ See, e.g., Macey \& Miller, supra note 2, at 53 (noting that, in determining the expected outcome, "[a]t issue ... is not what the trial court believed, but what the plaintiffs' attorney reasonably believed").

${ }^{168}$ See, e.g., Brookings TASK Force On Civil Justice Reform, Justice FOR AlL: REDUCING COSTS AND DELAYS IN CiVIL LiTIGATION 35 (1989) ("[T]here is a consensus that some litigation costs are not demanded by the merits of the case, but rather are incurred as a direct outgrowth of the incentives that have been built into the private legal industry itself."); Steven A. Burns, Note, Setting Class Action Attorneys' Fees: Reform Efforts Raise Ethical Concerns, 6 GEO. J. LEGAL ETHICS 1161, 1166 (1993) (observing that class action lawyers may be tempted to "overclaim hours worked and pad their bills"). 
Table 4: Effects of Ethical vs. Unethical Attorney Behavior

\begin{tabular}{lcc} 
& $\begin{array}{c}\text { Ethical } \\
\text { (no “churning”) }\end{array}$ & $\begin{array}{c}\text { Unethical } \\
\text { (with “churning”) }\end{array}$ \\
\hline \hline True Value & 750 & 750 \\
Lodestar & 5 & 8 \\
Max fee & 20 & 32 \\
Breakpoint & 100 & 160 \\
(with cushion) & & 160 \\
Settlement & 100 & 32 \\
Fees & 20 & 128 \\
Class members' & 80 & \\
compensation & & \\
\hline
\end{tabular}

Note, too, that the lawyers have increased class members' compensation by $\$ 48$ million, and that they did it all by ginning up $\$ 3$ million in additional billable hours. Or, to put it conversely: if the lawyers act as rational-but-ethical economic actors (as we expect they will), they will cost their clients $\$ 48$ million.

So not only has the misguided obsession with attorney compensation and agency costs begotten a system that always retards the deterrent power of class actions and usually fails to promote the value of class compensation, but, in addition, this obsession with protecting class members from supposedly avaricious class counsel has also, irony of ironies, aligned class member interests with the very unethical behavior that inspires the compensationalist critique.

Nonetheless, in the face of these perverse constructs, over time plaintiffs' lawyers have developed business structures to serve the interests of funding and effectively prosecuting complex class actions within ethical bounds. And here again, as discussed below, one's view of these structures is likely to vary according to whether one has accepted deterrence of corporate wrongdoing as the animating project of small-claims class actions.

\section{B. Examining the Organizational Model of Class Action Lawyering}

The class action bar is a highly evolved organism. Over time, it has developed structures to achieve three key objectives: (1) effectively prosecute the action, (2) generate sufficient lodestar to warrant 
a return that offsets the risks, and (3) fund the litigation. From the perspective of deterrence, these complex structures are remarkably efficient, enabling ad hoc consortia of entrepreneurial lawyers to tackle massive litigation projects. ${ }^{169}$ We suspect, however, that these same structures appear grotesque when viewed from the traditional agency costs perspective.

The dominant class action model is a pyramid-shaped structure comprised of numerous small law firms. Two or more co-lead counsel typically sit at the top of the pyramid. ${ }^{170}$ The co-lead counsel are empowered to make all decisions relating to the litigation, and to submit a unified fee application at the close of the case. Beneath them on the pyramid are lawyers tasked with responsibility for important areas

169 The capacity for massive lodestar generation is readily apparent in the context of a large, well-financed law firm, which can flip a switch and produce prodigious swells of associate billings, spending its own cash as it awaits a payout somewhere down the line. See, e.g., Halfteck, supra note 9, at 55 n.181 (noting that law firm-specific attributes include "the opportunity to exploit firm-wide economies of scale and scope; the relative efficiency of a firm's investment in law enforcement; and the firm's position on an industry-wide learning curve"). That capacity is less apparent in the context of small plaintiffs' firms. Over twenty years ago, Professor Coffee asserted:

[P] laintiffs' [class action] attorneys are chronically underfinanced. Given the small size of the typical plaintiffs' firm, its cash flow predictably will be more volatile than that of a larger, more diversified firm, and it will probably have smaller capital reserves. ...

At the same time, the cost of undertaking a complex action has grown significantly in recent years to the point where it can strain or exceed the borrowing capacity of most plaintiffs' firms.

John C. Coffee, Jr., The Unfaithful Champion: The Plaintiff as Monitor in Shareholder Litigation, LAW \& CONTEMP. PROBS., Summer 1985, at 5, 57 (footnote omitted).

Less obvious, however, are the workings of ad hoc groups of small law firms, which remain the dominant model for the prosecution of consumer, antitrust, and most other class actions outside of the securities area. See, e.g., Richard A. Epstein, One Stop Law Shop, LEGAL AFFAIRS, Mar.-Apr. 2006, at 34, 37 ("Many large class-actions involving antitrust and consumer-fraud issues ... are handled by ad hoc alliances among multiple firms that split their labor and share the rewards of litigation.").

${ }^{170}$ The number of co-lead counsel varies, depending on the size of the case, the potential liabilities of the defendant(s), and the likelihood and amount of recovery or fee award. See generally Fisch, supra note 25, at 53, 78-80 (describing developments leading to the appointment of multiple lead counsel in complex litigation). When appointing multiple lead counsel, courts tend to consider whether such appointment will lead to redundancy or otherwise inappropriately boost the ultimate fee award. See, e.g., In re Donnkenny Inc. Sec. Litig., 171 F.R.D. 156, 158 (S.D.N.Y. 1997) (allowing the lead plaintiff to select two firms as lead counsel, "provided that there is no duplication of attorneys' services, and the use of co-lead counsel does not in any way increase attorneys' fees and expenses"). 
of the case and, in the lower strata, attorneys whose duties include the yeoman's work of document review and so forth. ${ }^{171}$

Strikingly, the co-leads are empowered to determine what multiplier to apply to firms or attorneys at each level of the pyramid. ${ }^{172}$ Each firm submits its lodestar-that is, a record of the hours and hourly rates of its participating lawyers-to co-lead counsel. The coleads then collate the hours, writing off duplicative, unauthorized, or otherwise noncompensable time, and submit a unitary fee application to the court. Once the award is made, the co-leads, in their sole discretion, determine the distribution. If a court awards a multiplier of, for example, $4 x$-lodestar, the co-leads might assign a multiplier of 1.0 to the bottom level of participating lawyers, 1.5 to the middle, 2.5 to "middle managers," and so forth. More senior lawyers, who were responsible for brief writing, key depositions, and the like, might receive multipliers as high as 3.0 or the full "case multiplier" (here, 4.0) if it was negotiated beforehand. The differential between the case multiplier and the multiplier received by any particular firm represents "profit," which is divided among the co-lead counsel.

Most interesting, for present purposes, are the peculiar economics of the pyramid's bottom levels. Courts award attorneys' fees "commensurate with the rates prevailing in the community" for similar services. $^{173}$ In big cities, where major class actions tend to be litigated,

${ }^{171}$ In most large cases, counsel form committees and receive titles such as "Chair of Discovery" or "Executive Committee Member." These striations serve multiple administrative and operational purposes, allowing the ad hoc structure to operate more like a unitary firm. See, e.g., Nager v. Websecure, Inc. [1998 Transfer Binder Supp.] Fed. Sec. L. Rep. (CCH) If 90,153 (D. Mass. Nov. 26, 1997) (approving the selection of three firms to serve as an "executive committee" to manage the litigation in order to "minimize the potential for disputes about the direction of the litigation").

${ }^{172}$ This power is often set forth in an order of the court appointing co-lead counsel and enumerating their responsibilities. Even where the authority to divide up fees is not expressed in this fashion, industry custom and a complex social system of mutual investment dictate that lawyers lower in the hierarchy accord co-lead counsel substantial discretion in the assignment of multipliers. Where disputes do arise, anecdotal evidence suggests that court-appointed mediators, special masters, and magistrates are likewise deferential to lead counsel's determinations on these matters. See, e.g., In re Xcel Energy, Inc., Sec., Deriv. \& ERISA Litig., 364 F. Supp. 2d 980, 1000 (D. Minn. 2005) (awarding attorneys' fees "to be distributed . . . in a manner that plaintiffs' colead counsel shall determine in their discretion"); In re Vitamins Antitrust Litig., 398 F. Supp. 2d 209, 225 (D.D.C. 2005) (upholding, for the most part, lead counsel determinations on how to divide $\$ 123$ million in attorneys' fees among various law firms).

${ }^{173}$ Yurman Designs, Inc. v. PAJ, Inc., 125 F. Supp. 2d 54, 58 (S.D.N.Y. 2001) (citation omitted). 
the prevailing rates for junior associates-who perform most document review work-are $\$ 200$ or more per hour. ${ }^{174}$ In many markets off the beaten path, freelancing lawyers are widely available to staff document reviews at, say, $\$ 35$ per hour. An enterprising lead counsel, then, might tap an experienced yet inexpensive labor pool by establishing a document review operation in some far-flung locale. ${ }^{175}$

The spread between the \$35-per-hour rate and the potential premultiplier recovery of up to $\$ 250$ per hour allows the consortium of small firms to access the capital and labor pool required to take on large, well-funded defense firms. Typically, the co-lead counsel will approach other firms and propose that they "sponsor" a reviewer, paying her (in this example) $\$ 35$ per hour for up to 1000 hours over the course of the project. The sponsoring firm may never actually meet this reviewer; the relationship is purely a financial investment. The sponsoring firm then pays the reviewer $\$ 35,000$ over the course of the review. At the end of the case, the sponsoring firm submits time records reflecting 1000 hours of work by the reviewer, and seeking compensation at a rate of $\$ 250$ per hour, for a (premultiplier) lodestar of $\$ 250,000$.

If the court awards a case multiplier of $3 x$-lodestar, each hour of the reviewer's work is paid out at $\$ 750$. Typically, most or all of the "profits"- that is, the difference between $\$ 250$ and $\$ 750$-will go upstream to be split among the co-lead counsel. The net result, if the case is successful, is that the sponsoring firm receives $\$ 250,000$ for its $\$ 35,000$ investment. $^{176}$ If the sponsoring firm is adept at evaluating the prospects of the underlying cases, the class action model presents extraordinary investment opportunities at the bottom of the pyramid.

${ }^{174}$ See, e.g., More Data To Add to Your Review of Billing Rates, LAW OfFICE MGM'T \& ADMIN. REP., Jan. 2004, at 1, 13-14 (finding that hourly rates for "associates in major metropolitan areas (New York, Los Angeles, San Francisco and Washington) ... range from $\$ 202$ to $\$ 243$ per hour for first-years to a high of $\$ 256$ to $\$ 358$ per hour for the class of 1996"); Jerry Crimmins, Survey: Partners Here Bill 1600 Hours Per Year, CHI. DAILY L. Bull., Aug. 1, 2006, at 1 ("New York associates from the class of 2005 charge an average rate of $\$ 230$ per hour.”).

${ }^{175}$ See, e.g., Halfteck, supra note 9, at 37 n.112 (noting that "large-scale class action law enforcement often draws upon not only the representing plaintiffs' law firms themselves but, increasingly, satellite professional-services firms who offer litigation consulting and various information-management services").

${ }^{176}$ This assumes that the co-leads submit the full 1000 hours at the requested rate, and that the court awards at least the lodestar claimed in the fee application. 
If the chance of winning each case well exceeds $10 \%$, then ten-to-one odds will pay off handsomely over time. ${ }^{177}$

This structure plainly serves the objectives of the ad hoc consortium: it allows the consortium to finance and effectively prosecute the class action, bringing to bear resources that rival those of the mammoth corporate law firms that are retained to defend significant class action litigations. In this way, the class action structure well serves the interests of deterrence. Viewed from the traditional compensationalist/agency-cost-obsessed/antiwindfall perch, this model may appear something of a nightmare-a naked lodestar factory. ${ }^{178}$ From the more reasoned deterrence perspective, however, this model represents a socially useful adaptation to a grossly inefficient set of rules.

\section{Reexamining Coupon Settlements and CAFA}

By now, it should be fairly clear that rejecting the compensationalist viewpoint sheds a different light on the rules and practices involved with class actions. Another example of a class action practice illuminated by a shift from the compensationalist view is coupon-based settlements. ${ }^{179}$ In enacting provisions of CAFA that deal with coupon settlements, Congress's intent was explicit: "Class members often receive little or no benefit from class actions, and are sometimes harmed, such as where . . counsel are awarded large fees, while leaving class

${ }^{177}$ See generally Halfteck, supra note 9, at 19-20 ("From the investment perspective of plaintiffs' attorneys, the reality of modern mass society comprises a pool of investment opportunities, where they may invest financial wherewithal and intellectual capital to discover and prosecute potential wrongdoing.").

${ }^{178}$ Professor Resnik notes:

Despite a legal and popular press filled with stories about large sums paid, collusion, the possibility of kickbacks or payoffs, and entrepreneurial excesses, judges-in general-do little to superintend how lawyers divide money among themselves, which lawyers are paid for what services, or what "side settlements" (made either between lawyers or between defendants and subsets of litigants) are permissible.

Resnik, supra note 13, at 2122 (footnotes omitted).

${ }^{179}$ "In coupon settlements, instead of a cash award, plaintiffs receive coupons or other promises for products or services." Hantler \& Norton, supra note 52, at 1344. For a general and critical discussion of pre-CAFA coupon-based settlements, see Leslie, supra note 47, at 994 (asserting that defendants may structure settlement coupons in ways that make the settlement worthless for many (and sometimes most) class members). 
members with coupons or other awards of little or no value." ${ }^{180}$ In response, CAFA requires courts to carefully scrutinize these settlement deals, but it stops short of telling judges precisely what standards to employ in doing so. ${ }^{181}$

Nevertheless, Congress's starkly compensationalist framing of the issue certainly tracks the orthodox literature, which would disallow any coupon-based settlement that does not provide a meaningful net financial benefit to the class member. ${ }^{182}$ The test, in this view, is whether the coupons distributed are valuable to the class member recipients. A deterrence-centric perspective is different. We care only that the coupon issuance will inflict pain on the wrongdoer.

A court scrutinizing a settlement may well find that value to the consumer and detriment to the issuer are two very different things. The face value of a coupon to the consumer may be low, and yet a court might find, based on evidence presented at a fairness hearing, that the redemption rates likely will be sufficiently high to inflict a meaningful aggregate detriment upon the defendant issuer. ${ }^{183}$ This might be the case where, for example, the good or service covered by the coupon is one that class members would purchase on a regular basis, ${ }^{184}$ and coupon issuance will not "actually lead to additional profits for a defendant." ${ }^{185}$ A court might also be influenced by the possibility that a third-party aggregator might swoop in and purchase all of the coupons from the claims administrator, ${ }^{186}$ producing a pot of

${ }^{180}$ Class Action Fairness Act of 2005, Pub. L. No. 109-2, § 2(a) (3), 119 Stat. 4 (2005).

${ }^{181}$ Id. $\S 3(\mathrm{a})$ (codified at 28 U.S.C.A. \$ 1712(e) (West 2005)) (requiring that a coupon-based settlement be approved only if the court conducts a fairness hearing and makes written findings that the settlement is "fair, reasonable, and adequate for class members").

182 See, e.g., Hantler \& Norton, supra note 52, at 1346 (asserting that "injured class members often do not receive real compensation" in coupon-based settlements).

${ }^{183}$ From the entrepreneurial lawyer's perspective, it is important to show that redemption rates will be high, as CAFA requires that only the value of coupons actually redeemed be considered where coupons are the basis for awarding attorneys' fees. 28 U.S.C.A. \$ 1712(a) (West 2005).

184 See, e.g., O’Keefe v. Mercedes-Benz USA, LLC, 214 F.R.D. 266, 303 (E.D. Pa. 2003) (approving a settlement involving $\$ 35$ vouchers for oil changes where "[a]ll vehicles need an oil change eventually and all vehicle owners anticipate oil changes.").

${ }^{185}$ Judge D. Brock Hornby, Outline, Fed. Trade Comm'n Workshop Panel: The Use of "Coupon" Compensation and Other Non-Pecuniary Redress 2 (Sept. 13, 2004), available at http://www.ftc.gov/bcp/workshops/classaction/writ_materials/hornby.pdf.

${ }^{186}$ See James Tharin \& Brian Blockovich, Coupons and the Class Action Fairness Act, 18 GEO. J. LEGAL ETHICS 1443, 1443, 1449 (describing the work of a company that buys 
money that can be distributed either to plaintiffs or to a charity by way of a cy pres distribution. ${ }^{187}$ As long as the transaction causes the defendant to internalize the social costs of its wrongdoing to some meaningful degree, a properly oriented court ought to approve the settlement. ${ }^{188}$

Similarly, courts guided by the polestar of forced internalization of social costs will not hesitate to approve cy pres settlement distributions or fluid class recoveries, ${ }^{189}$ and will award attorneys' fees in the $c y$ pres context on a percent-of-fund basis, just as they would if the settlement funds were distributable to class members. By contrast, the compensationalist approach, as enshrined in CAFA, expressly prohibits attorneys' fees to be calculated on the basis of any portion of $c y$ pres relief awarded in a coupon-based class settlement. ${ }^{190}$ This restriction "departs significantly from established practice," as cy pres relief "usu-

coupons from class members and resells them on the secondary market, and arguing that a strong "market maker" is necessary for coupon settlements to benefit consumers).

${ }^{187}$ Compensationalists have been critical of efforts to rehabilitate the value of coupons on the secondary markets. See, e.g., Christopher R. Leslie, The Need To Study Coupon Settlements in Class Action Litigation, 18 GEO. J. LEGAL ETHICS 1395, 1404 (2005) ("Transfer restrictions can prevent market makers from making settlement coupons truly valuable."); Tharin \& Blockovich, supra note 186, at 1447 ("Rules of redemption and enforcement are rarely sufficient to seamlessly redeem a coupon, and few coupons are saleable at any price. Most coupons are burdensome, restrictive and confusing. ... The defendant's legal department controls the process, preferring to quell redemptions rather than promote redemptions.").

We are more optimistic, and believe that as long as coupons (1) are freely transferable, (2) may be transferred multiple times without losing value, (3) contain no restrictions on aggregation, and (4) do not expire quickly (all of which a judge can easily mandate upon approving a coupon-based settlement), secondary markets will necessarily develop at competitive face-value rates.

${ }^{188}$ As an aside, anecdotal evidence suggests that a very small percentage of settling class actions provide coupon-only benefits. See Lisa Mezzetti, Partner, Cohen Milstein, Comments at the FTC Workshop: Protecting Consumer Interests in Class Actions (Sept. 13, 2004) in 18 GeO. J. Legal ETHICS 1161, 1178 (2005) (questioning the "emphasis on coupon settlements," given the "very small percentage" of coupon-only settlements).

${ }^{189}$ See, e.g., Michael Northrup, Restrictions on Class-Action Attorney-Fee Awards, $46 \mathrm{~S}$. TEX. L. REv. 953, 964 (2005) (describing the cy pres or fluid recovery doctrine, which comes from trust law, as authorizing courts "to put unclaimed or undistributed classaction recoveries to the next best use") (emphasis omitted).

${ }^{190} 28$ U.S.C.A. $\$ 1712$ (e) (West 2005) (providing that the "distribution and redemption of any proceeds" from coupon settlements "shall not be used to calculate attorneys' fees"). 
ally has been considered in awarding attorneys' fees." ${ }^{191}$ But more importantly for our thesis, discouraging plaintiffs' counsel from structuring coupon-based settlements that include cy pres relief has negative consequences for the deterrent values of such settlements.

\section{Reexamining Collective Action Waivers}

We offer one last example of how the rejection of compensationalist norms compels different analyses of class action issues; this one is drawn from our previous work examining collective action waiversclauses contained in standard-form adhesion contracts mandating one-on-one arbitration of disputes and waiving the right to seek classwide relief. ${ }^{192}$ Traditional critics of collective action waivers argue that when consumers enter into adhesion contracts, they do not assent in any meaningful way to the waivers; the fundamental critique is that a voluntary and knowing waiver of the individual's rights is lacking. ${ }^{193}$ The corporate defenders of the waivers, meanwhile, argue that business efficiency principles compel us to recognize or infer assent from contemporary transactions. ${ }^{194}$ We must find assent in shrinkwrap and

${ }^{191}$ Charles B. Casper, The Class Action Fairness Act's Impact on Settlements, ANTITRUST, Fall 2005, at 26, 28.

${ }^{192}$ See generally Gilles, Opting Out of Liability, supra note 12, at 391-412 (examining the use of contractual class action waivers).

${ }^{193}$ See, e.g., Mark E. Budnitz, Arbitration of Disputes Between Consumers and Financial Institutions: A Serious Threat to Consumer Protection, 10 OHIO ST. J. ON DISP. RESOL. 267, 342 (1995) (concluding that arbitration mandated by financial institutions may deprive consumers of the protections of the justice system); Linda J. Demaine \& Deborah R. Hensler, "Volunteering" To Arbitrate Through Predispute Arbitration Clauses: The Average Consumer's Experience, LAW \& CONTEMP. PROBS., Winter-Spring 2004, at 55, 56 (criticizing court decisions finding that individuals "may now be forced to arbitrate if the parties are deemed to have assented to a predispute arbitration clause"); Mara Kent, "Forced" vs. Compulsory Arbitration of Civil Rights Claims, 23 LAW \& INEQ. 95, 115 (2005) (arguing, in the context of forced arbitration of employees' civil rights claims as a condition of employment, that "[o] ur civil rights statutes would be significantly undermined if the courts allowed employers to force employees to choose between their statutorily protected civil rights and their jobs"); Jean R. Sternlight, As Mandatory Binding Arbitration Meets the Class Action, Will the Class Action Survive?, 42 WM. \& MARY L. REV. 1,6 (2000) (" $[\mathrm{I}] \mathrm{t}$ would be wrong to allow companies to use arbitration clauses to insulate themselves entirely from class action liability ....").

${ }^{194}$ For example, in Hill v. Gateway 2000, Inc., 105 F.3d 1147, 1150 (7th Cir. 1997), the court held that a purchaser of a computer was bound to the terms and conditions found inside the box, including an arbitration clause, unless he returned the computer within a thirty-day period. Judge Easterbrook's decision "encapsulate[d] the move from a consent-based to an efficiency-based theory of contract law .... The only value here is efficiency; consent is irrelevant." Gilles, Opting Out of Liability, supra note 12, at 
scroll-text licenses, box-stuffer notices, and so forth, lest the wheels of contemporary commerce stop spinning. ${ }^{195}$

The normative polestar of deterrence tells us that both arguments are off course. Waivers of collective action rights undercut deterrent values. It does not matter whether knowing and voluntary waivers are obtained; the class action is not the individual consumer's procedure to waive. ${ }^{196}$ The goal of forcing defendants to internalize the social costs of their actions requires that the class action remain a viable instrument in any given case. Collective action waivers, then, are exercises in pure social disutility.

\section{FINALLY ASKING THE Right QUESTIONS: THE Problems of Suboptimal DETERRENCE}

Our thesis is not that current class action practices and rules optimally deter. It is that they should. The goal of improving the deterrent function of class suits provides the singular lens through which we should examine these practices. In particular, we should be sensitive to the concerns of whether current class action practices over- or underdeter.

\section{A. The Overdeterrence Problem}

If we measure class action rules and proposals by whether they increase deterrent value, do we not run the risk of overdeterring effi-

\footnotetext{
414-15 (footnotes omitted); see also Clayton P. Gillette, Rolling Contracts as an Agency Problem, 2004 WIS. L. REV. 679, 682 (noting that cases upholding such unilateral contracts "appear motivated by the utility and practicality of easy forms of contracting").

195 Gilles, Opting Out of Liability, supra note 12, at 415 ("Judge Easterbrook postulates that the price of establishing meaningful consent-in the explicit, meeting-of-theminds sense of the word-would be to grind contemporary commerce to a halt.”).

${ }^{196}$ If we believe the argument that "consumers-given the choice-may opt to waive their right to collective action if that meant cheaper goods and services," "then why not allow companies to require consumers . . . to waive all prospective liability ... in exchange for a reduction on price, or a bump up in wages?" Id. at 429. "[C]urrent legal doctrine doesn't allow it: as a matter of public policy, we prohibit prospective waivers of federal statutory liability." Id. In many ways, our view that the waiver of collective litigation rights by individual consumers is irrelevant mirrors our argument that compensation to individual class members in small-claims class actions is irrelevant. In both scenarios, the rhetorical and political use of the individual litigant as having "rights" is manipulated by the very institutions-big business, defense firms, the U.S. Chamber of Commerce, etc.- who wish to see the incidence of liability for violations of those "rights" reduced.
} 
cient behavior? After all, to deter optimally is not to deter maximally. Our conclusion is that we need not worry too much about this. Where class actions survive dispositive motions, ${ }^{197}$ they settle. ${ }^{198}$ And when parties settle, they settle for less-significantly less-than the full value of the social loss created by the defendant's actions. ${ }^{199}$ Indeed, the only time a defendant is forced to internalize costs that exceed the social costs of its actions is, we suspect, when a case goes to judgment, ${ }^{200}$ and punitive or treble damages are imposed. While one can argue whether or not punitive damages have social utility, the class action arena is an odd place to have that particular debate, given that nearly all class actions that survive dispositive motions settle.

Some scholars-notably John Coffee-have argued that class actions probably do extract more than the requisite pound of flesh in the case of "piggyback" or "follow-on" class actions. In these suits, plaintiffs' class action lawyers "simply piggyback[] on the [enforcement] efforts of public agencies-such as the SEC, the FTC, and the Antitrust Division of the Department of Justice (DOJ) - in order to

${ }^{197}$ See Silver, supra note 74, at 1399 (concluding, based on a review of data on summary judgment motions in class action litigation, that "many" class actions "end in dismissals, not settlements").

${ }^{198}$ See Casper, supra note 191, at 26 (discussing a study of individual and class action antitrust cases finding that $71 \%$ to $88 \%$ of those cases settled before trial, and three studies finding that between $80 \%$ and $90 \%$ of securities class actions settled); Willging et al., supra note 122, at 66,115 fig.7, 167 tbl.16 (finding that $53 \%$ to $64 \%$ of class actions studied settled, only $3 \%$ to $6 \%$ went to trial, and, of those that went to trial, $28 \%$ settled during or after trial).

${ }^{199}$ It is possible that some defendants settle to avoid the costs of the class action procedure, even though the claims would surely-or almost surely-fail on the merits. See, e.g., Hay \& Rosenberg, supra note 71, at 1402 ("Risk averse parties will pay a premium to avoid taking a gamble."); Note, Risk-Preference Asymmetries in Class Action Litigation, 119 HARV. L. REV. 587, 600 (2005) (noting that in a "low-merit suit" the defendant's risk aversion will be heightened, and a "risk-averse defendant would likely pay a high premium to avoid the variance of a class action trial"). It is also possible that a defendant may have struggled earnestly to conform to vague consumer protection or other laws, only to fall short in circumstances that impose little cost on society. Imposing liability in these circumstances may result in overdeterrence as others, faced with still-ambiguous law, refrain from socially useful activities. We thank Professor Edward Cooper for pointing these issues out to us. If we are to trust, however, that courts can do a fairly good job at vetting frivolous and nonmeritorious cases through motion practice-as evidenced by Professor Silver's conclusion that most class actions end in dismissals, see supra note 74 and text accompanying note 197-these concerns should not be overstated.

${ }^{200}$ Cf. Coffee, Rescuing the Private Attorney General, supra note 34, at 225 (concluding that "the deterrent threat of the private attorney general has been blunted" because so few private litigations reach the judgment stage). 
reap the gains from the investigative work undertaken by these agencies." ${ }^{201}$ The result of these follow-on class actions, according to Coffee, is not a broader "scope of law enforcement" or better deterrence, but only an intensified penalty. ${ }^{202}$

The real question here, it seems to us, is whether the penalties inflicted in a follow-on private class action, after government agents have already imposed some sanction, cause the corporate wrongdoer to internalize more than $100 \%$ of the social costs of its actions. We are skeptical of that assumption. In seeking corrective action and levying fines, government enforcement agencies act with knowledge of the claims of class action plaintiffs. ${ }^{203}$ The SEC, FTC, and DOJ all

${ }^{201} I d$. at 222. Coffee describes the "spectacle ... in which the filing of the public agency's action serves as the starting gun for a race between private attorneys, all seeking to claim the prize of lucrative class action settlements, which public law enforcement has gratuitously presented them." Id. at 228; see also Coffee, Understanding the Plaintiff's Attorney, supra note 7, at 681 (describing class actions sparked by government investigations); Bryant Garth et al., The Institution of the Private Attorney General: Perspectives from an Empirical Study of Class Action Litigation, 61 S. CAL. L. REV. 353, 376 (1988) (describing evidence supporting the claim that "private attorneys tended to 'piggyback' their cases on governmental investigations, even to the extent of copying the government's complaint"); John E. Kennedy, Securities Class and Derivative Actions in the United States District Court for the Northern District of Texas: An Empirical Study, 14 Hous. L. REv. 769, 824 (1977) (estimating that "about half of the representative securities litigation is related to a prior SEC or bankruptcy proceeding”). In a recent essay, Professor Coffee acknowledges that in the area of securities regulation, private class actions "represent the principal means by which financial penalties are imposed" on defendants, "overshadowing the aggregate penalties imposed by federal and state authorities and by self-regulatory organizations." Coffee, Securities Class Action, supra note 1 , at 4 .

${ }^{202}$ Coffee, Rescuing the Private Attomey General, supra note 34, at 223. While Coffee recognizes that an increased penalty may serve some laudatory functions, he remains pessimistic that deterrence is optimized in this way. See id. at 225-26 (discussing two problems with follow-on class actions: private enforcement does not yield actions that would not have been instigated by public efforts alone, and private watchdogs often accept inadequate settlements in return for higher-than-ordinary fee awards). Other, more partisan observers believe that the increased penalty may actually be harmful. See Beisner et al., Class Action Cops, supra note 93, at 1455 (arguing that class action lawyers filing follow-on class actions increase the penalty beyond "the limits established by law" and usurp the role "traditionally entrusted to expert regulatory agencies and state attorneys general”).

203 Enforcement agencies explicitly rely on private enforcement actions to supplement their efforts. See, e.g., HENSLER ET AL., supra note 15, at 69 (quoting former SEC chair Arthur Levitt's testimony before the 1995 U.S. House subcommittee considering class action reform: "Private actions ... provide a necessary supplement to the commission's own enforcement activities by serving to deter securities law violations"); Cruz Remarks, supra note 100, at 15 (observing that "piggyback" private class actions "can provide an efficient mechanism for directing compensation to injured consum- 
know that the real financial wallop, in most instances, will come from the private class actions that follow their investigations. ${ }^{204}$ In imposing penalties, it would be irresponsible for government actors to ignore these facts; indeed, strong evidence supports our assertion that they do not. ${ }^{205}$ In the end, we suspect that most piggyback class actionslike all other class actions-settle for a modest percentage of the overall loss imposed, even factoring in government penalties. ${ }^{206}$

Another common overdeterrence concern lies in "[n]onmeritorious class actions filed by lawyers who expect defendants to be willing to pay something simply to ensure that the class counsel will 'go away,' ... [thus] dilut[ing] the deterrent effect of class action litigation." ${ }^{207}$ Here again, our sense is that this argument is somewhat overblown. Class action practice in the real world is characterized by a very high incidence of successful motions to dismiss, successful mo-

ers, particularly where the underlying Commission action seeks only injunctive relief"); FTC Press Release, supra note 94 (quoting ex-FTC chairman Thomas B. Leary as having noted that " $[\mathrm{t}]$ he Federal Trade Commission is a relatively small agency with broad competition and consumer protection responsibilities.... We depend on private litigation to supplement our efforts"). Indeed, the SEC's website goes so far as to advise potentially defrauded investors to "find out whether a private class action has been filed against the company you invested in," and provides a link (labeled "private class action") to the Stanford Law School Securities Class Action Clearinghouse at http://securities.stanford.edu. See Sec. \& Exch. Comm'n, Investor Claims Funds, http://www.sec.gov/divisions/enforce/claims.htm (last visited Oct. 21, 2006).

${ }^{204}$ See Coffee, Securities Class Action, supra note 1, at 10 (citing the results of a study by Harvard Law Professor Howell Jackson showing that private securities class action settlements "averaged an annual aggregate amount (i.e., \$1,906,333,333) exceeding the sum of all public monetary sanctions"); $i d$. at 11 (presenting the results of a study by Cornerstone Research and concluding that "even in major scandals where the SEC has brought its own action, the damages paid in securities class actions are usually (but not always) a multiple of those paid to the SEC").

${ }^{205}$ See supra note 203 (describing SEC and FTC reliance on private class actions as a supplemental enforcement technique). As many commentators have suggested, public enforcement agencies often lack the resources to rigorously investigate and enforce claims, and "may be constrained also by political influence" to ignore some claims. HENSLER ET AL., supra note 15, at 69.

${ }^{206}$ We are not aware of any empirical work comparing the penalties meted out by public enforcement agencies to the settlements negotiated by the private class action bar in order to determine whether the former fails to effectively deter. The closest we have seen is a study in which the authors reviewed 248 securities fraud class actions and found the private suits that paralleled SEC investigations and actions settled more quickly and for significantly more money than did the independent suits. James D. Cox \& Randall S. Thomas, SEC Enforcement Actions for Financial Fraud and Private Litigation: An Empirical Inquiry 16-19 (Vanderbilt Univ. Law Sch., Law \& Econ. Working Paper No. 03-08, 2003), available at http:/ / papers.ssrn.com/absract_id=429140.

${ }^{207}$ Hensler \& Rowe, supra note 41, at 137. 
tions for summary judgment, and unsuccessful motions for class certification. ${ }^{208}$ Why should we assume that class action defendants are pushovers? Meritless filings are not met with payoff money; they are met with motion practice, ${ }^{209}$ and sometimes sanctions. Defendants not only fight back, they also ferret out fraud, as in the recent "Silica cases," in which the defendants uncovered evidence that may yet land plaintiffs' lawyers and medical experts in jail. ${ }^{210}$

The important point in all of this is not whether we are right or wrong in our assessment of whether current class action rules, in some general way, tend to overdeter. While we may doubt that they do, the point here is only that these are the questions we should be asking whenever we examine particular rules, practices, and reform proposals in the class action arena.

\section{B. The Underdeterrence Problem}

A more pressing concern is whether class actions underdeter: whether current rules prompt plaintiffs' lawyers to settle for too little, so that defendants are not forced to internalize the full costs of their wrongdoing. As we have already discussed, the major villain here is the lodestar cross-check, which undermines deterrence by driving attorneys to settle cases at settlement-incentive breakpoints that fall short of true settlement values.

Other underdeterrence arguments are underwhelming. The most prevalent relates to "the ability of defendants and the plaintiff's attor-

208 See Silver, supra note 62, at 1399 (describing the incidence of class actions disposed of through motions to dismiss and motions for summary judgment); Willging et al., supra note 122, at 8 (summarizing data on class actions dismissed by summary judgment, motions to dismiss, or denial of class certification).

${ }^{209}$ We suspect this inclination to file motions is driven by a self-interested defense bar, which properly advises its client base that over the long haul, repeat defendants are better served by paying their lawyers to stand and fight rather than paying the plaintiffs to go away.

${ }^{210}$ In the Silica cases, see generally In re Silica Prods. Liab. Litig., 398 F. Supp. 2d 563 (S.D. Tex. 2005), headlines were made when a Texas judge overseeing "about 120 silicosis suits involving some 10,000 plaintiffs" "accused doctors, screening companies and the plaintiffs' lawyers of being involved in a 'scheme"' to diagnose otherwise healthy plaintiffs with this lung-scarring disease. Mary Alice Robins, U.S. House Committee Asks Texas Firms for Silicosis Suit Info, TEX. LAWYER, Feb. 27, 2006, at 4. It was the defendants' persistence and willingness to litigate the underlying medical issues that led to these discoveries. In addition to an ongoing congressional investigation into the plaintiffs lawyers' role, the defendants are also seeking steep sanctions for the filing of baseless litigation. Id. 
neys to arrange collusive settlements that exchange a low recovery for a high fee award." ${ }^{211}$ The nub of this concern is that defendants, who

"care only about the total amount they must pay out in settlement [of a common fund case], not how the payoff is distributed between class members and the class lawyer." Thus, defendants have a strong incentive to offer class counsel a deal in which the defendants accede to increased class counsel fees in return for the class counsel's agreeing to a lower recovery for class members. ${ }^{212}$

Or, in Professor Coffee's more provocative prose: “The ability of private law enforcement to create a credible penalty structure is undercut if the private watchdog can be bought off by tossing him the juicy bone of a higher-than-ordinary fee award in return for his acceptance of an inadequate settlement."213

This critique, however, is a canard; in reality, the defendants have no such "juicy bones" to toss to the plaintiffs' lawyers. While fee rules in common fund cases may differ across federal jurisdictions, not one district (to our knowledge) allows defendants and plaintiffs' counsel to agree to the amount of attorneys' fees to be paid out of the fund. Such a regime would be totally inconsistent with a lodestar, percentof-fund, or lodestar cross-check approach. The reality is that class action fees are set by courts, not by agreement between the parties. Nor is there any merit to the notion that defendants are selling a promise to remain silent and not contest the fee application. They will remain silent anyway. They have no dog in that hunt.

Underdeterrence remains a huge concern in several other areas of class action practice. For instance, plaintiffs may sue for injunctive relief and damages and then collude with the defendant to settle the

${ }^{211}$ Coffee, Understanding the Plaintiff's Attorney, supra note 7, at 691. "At its worst, the settlement process may amount to a covert exchange of a cheap settlement for a high award of attorney's fees." Id. at 714; see also RICHARD A. POSNER, ECONOMIC ANALYSIS OF LAW 627 (5th ed. 1998) ("[T] he lawyer for the class will be tempted to offer to settle ... for a small judgment and a large legal fee, and such an offer will be attractive to the defendant, provided the sum of the two figures is less than the defendant's net expected loss from going to trial.").

${ }^{212}$ Susan P. Koniak \& George M. Cohen, In Hell There Will Be Lawyers Without Clients or Law, 30 Hofstra L. Rev. 129, 146-47 (2001) (quoting Susan P. Koniak \& George M. Cohen, Under Cloak of Settlement, 82 VA. L. REV. 1051, 1111 (1996)). The authors further assert that "[d] efendants and their lawyers in class action suits understand the agency [cost] problem ... and have every incentive to exploit it." Id. at 146.

${ }^{213}$ Coffee, Rescuing the Private Attorney General, supra note 34, at 226. 
case for damages only. ${ }^{214}$ In many cases, defendants will pay dearly for this privilege because the injunction is what concerns them most (since it will end their ability to continue the lucrative but unlawful practice). Entrepreneurial plaintiffs' lawyers will be quick to cut such a deal because injunctions do not contribute to the common fund, whereas money damages do. Therefore, the one true lens of deterrence dictates that courts view with skepticism the abandonment of equitable claims in class settlement agreements.

Another practice that raises serious underdeterrence concerns is the so-called "reverse auction" phenomenon. Where multiple class actions are filed alleging the same wrongdoing against the same defendant, there is an opportunity for the defendant to engage in a "reverse auction" by pitting plaintiffs' firms against one another in hopes of achieving the cheapest and most comprehensive settlement. ${ }^{215}$ Even if notice of the proposed settlement is given to all affected parties, the effects are often perverse. One reporter described the efforts of an attorney who spent "two years in a game of legal whack-a-mole, flying to courts in Florida, Illinois and Texas to beat back the settlement offers that pop[ped] up [just as he had] an expensive [class ac-

${ }^{214}$ Hantler and Norton observe that serious conflicts of interest occur "in noncash, or coupon class actions, [where] there often is no settlement fund or pool from which the plaintiffs' lawyers can draw their contingency fee." Hantler \& Norton, supra note 52, at 1356 . They suggest that the "most sensible approach for companies to take with non-cash settlements ... is to negotiate the benefit to the plaintiff class with the plaintiffs' attorney first, and then insist that the judge overseeing the litigation determine the attorneys' fees after the final settlement is presented to the court." Id. at 1356-57.

215 John C. Coffee, Jr., Class Wars: The Dilemma of the Mass Tort Class Action, 95 Colum. L. REv. 1343, 1370 (1995) ("The first team to settle with the defendants in effect precludes the others (who may have originated the action and litigated it with sufficient skill and zeal that the defendants were eager to settle with someone else)."); see also Charles Toutant, KPMG Pact Gets Conditional Nod, but Rival Plaintiffs' Firms Press On, 182 N.J. L.J. 561 (2005) (describing efforts by three plaintiffs' class action firms to disqualify Milberg Weiss as lead counsel on the grounds that it engaged in a reverse auction with defendants that eviscerated their pending class actions for too low a settlement); Pamela A. MacLean, You've Got Trouble, NAT'L L.J., reprinted in CORP. COUNS. MAG., Sept. 2005, at 142 (reporting that plaintiffs' class action lawyers federally enjoined a $\$ 25$ million state court-approved settlement of a class action against America Online on the grounds that the settling attorneys cooperated with the defendants in a reverse auction); Justin Scheck, Reverse Auctions Have No Class: Lawyers Square Off with Firms Trying To Undercut Settlements, THE RECORDER (S.F.), July 18, 2005, available at http://www.gdblegal.com/press.php?menuItem $=5 \&$ article $=46$ (citing ethics expert Joseph McMonigle, who stated that "competing filings can allow defendants to pick the plaintiff with the weakest case. With weaker opposition ... defense lawyers have more leverage to reach a cheap settlement"). 
tion] case headed to trial." ${ }^{216}$ Certainly, the enactment of CAFA will reduce the incidence of these types of deals by forcing many class actions into federal courts, where the Judicial Panel on Multidistrict Litigation will consolidate like claims in a single jurisdiction. ${ }^{217}$ But to the extent that CAFA does not terminate this practice, it is certainly appropriate for courts, applying the one true lens of deterrence, to evince great skepticism of any settlement resulting from a reverse auction process.

\section{CONCLUSION}

Even as economic analysis has come to dominate the class action arena, we have lost sight of Richard Posner's 1972 observation, regarding class actions, that "the most important point, on an economic analysis, is that the violator be confronted with the costs of his violation-this achieves the allocative purpose of the suit-not that he pays them to his victims." ${ }^{218}$ As a corollary, the vast contemporary literature of class actions (and, for that matter, the work of Congress and the courts) fails entirely to appreciate the concrete public policy implications of the one true normative polestar here: the forced internalization of social costs.

One interesting question is why the competing normative polestar of class member compensation is so pervasive in the academic literature, popular press, and halls of Congress. The answer may be a moral discomfort with entrepreneurial wealth-creation by plaintiffs' class action lawyers. If we strip away concerns with class member compensation, then current policies (for example, the lodestar crosscheck, or rules disallowing percentage-based fee awards on cy pres distributions) would have to be justified on other grounds. We suspect that even the most earnest scholars are uncomfortable arguing that

${ }^{216}$ Scheck, supra note 215.

217 See J. Douglas Richards, What Makes an Antitrust Remedy Successful?: A Tale of Two Settlements, 80 TUL. L. REV. 621, 656 (2005) (predicting that CAFA "should reduce the frequency of 'reverse auctions'... since most antitrust class actions that were previously brought in state court may now proceed together in federal court. . . . [This] also should ... mak $[\mathrm{e}]$ it easier to obtain class certification of multistate antitrust class actions in federal courts"); T.R. Goldman, Class Menagerie, LEGAL TIMES, reprinted in CORP. COUNS. MAG., Apr. 2005, at 72 (observing that because CAFA forces class actions into federal court "there will be fewer chances for companies to work the so-called reverse auction, which allows defendants to play one set of plaintiffs off another in order to achieve the lowest settlement price").

${ }^{218}$ POSNER, supra note 22, at 349-50. 
some inherent moral value compels otherwise arbitrary limitations on attorney compensation. It is only natural, then, that they should fall back upon the norm of protecting class member compensation.

Another reason for the primacy of compensation concerns, in certain circles, is plain old-fashioned hypocrisy. Corporate lobbyists and conservative commentators regularly purport to stand up for the right of absent class members to receive money damages by advocating rules that would severely limit the fees of class counsel. ${ }^{219}$ One could be forgiven, however, for suspecting that the real motivation of corporate advocates is not plaintiffs' rights, but rather (1) to diminish both the absolute number and efficacy of class actions by making them less attractive investment opportunities to effective entrepreneurial lawyers; ${ }^{220}$ and (2) to diminish the wealth and influence of plaintiffs' class action lawyers, who not only comprise the most effective lobbying counterweight to corporate interests in contemporary politics, but who use their wealth to finance further class action litigation against U.S. companies. ${ }^{221}$

Whatever the reason, as we have demonstrated, the orthodox imperative to reduce agency costs and protect class member compensation has ushered in a blizzard of bad policy choices. These choices undercut the deterrent value of class actions at practically every turn: from the rules for setting attorneys fees, to the standards we employ for approving settlements, to the way we evaluate waivers of the right

${ }^{219}$ See, e.g., Class Action Fairness Act Hearing, supra note 79, at 38 (testimony of John Beisner) (testifying in support of CAFA on the grounds that legislation would curb those "circumstances in which counsels walk off with enormous attorneys' fees but the class members receive next to nothing").

${ }^{220}$ See, e.g., Stephen Daniels \& Joanne Martin, "The Impact That It Has Had Is Between People's Ears:" Tort Reform, Mass Culture, and Plaintiffs' Lawyers, 50 DePaul L. Rev. 453,453 (2000) (noting that contemporary litigation reformers want "[m] ore than just the formal legal changes": they want to alter "the cultural environment surrounding civil litigation" by influencing the way the public responds to what "plaintiffs and their lawyers[] do with regard to naming and blaming").

221 See CRIER, supra note 53, at 193 (observing that, “[u] sing attorneys' fees earned in similar litigation, these industrious 'tort kings' bankroll the next generation of class action lawsuits"); GOULDEN, supra note 113, at xiii (observing that class action lawyers take their settlement proceeds and "turn around and invest in new 'liability areas'that is, areas they can exploit for even more lawsuits"); John T. Nockleby \& Shannon Curreri, 100 Years of Conflict: The Past and Future of Tort Retrenchment, 38 LOY. L.A. L. REV. 1021, 1021-22 (2005) (remarking that contemporary reformers have "made the strategic choice to politicize" their reformist campaign "in a very public effort to undermine the civil justice system" by torpedoing, among others, "lawyers [who] foment excessive litigation"). 
to seek class-wide relief. On virtually every issue, scholars and policymakers have been asking all the wrong questions. At best, in this Article, we have scratched the surface of a discourse that asks the right questions and which evaluates class action practices against a measuring stick of deterrence, unadulterated by the contemporary obsession with agency costs or solicitude for the compensatory interests of disinterested class members in small-claims class actions. 